\title{
PORESKE IMPLIKACIJE METODE OBRAČUNA ZARADE BUDŽETSKIH KORISNIKA
}

\section{Ljubomir Radević}

Ministarstvo odbrane Republike Srbije, Beograd, Srbija

\begin{abstract}
Apstrakt:
Propisi u oblasti poreskog sistema i socijalnog osiguranja Republike Srbije nisu se konceptualno menjali, uprkos činjenici da je ekonomsko uređenje zemlje u osnovi izmenjeno pre nekoliko godina. Sadašnji model dvostrukog zaračunavanja doprinosa (iz zarade i na zaradu) u stvari je nasleđeni model čiji je cilj bio da obezbedi (pored zdravstvene) penzionu sigurnost za zaposlenog. U ovom radu ćemo ukazati da postojeća neusklađenost između poreskog sistema i sistema penzijskog osiguranja u Republici Srbiji, pored značajnog poreskog opterećenja za poslodavca, dovodi do uvećanja penzijskog osnova jedne kategorije zaposlenih na štetu druge kategorije zaposlenih.
\end{abstract}

Ključne reči:

metode obračuna zarade, troškovi poreza i doprinosa, poreski uticaj na penzijsko osiguranje.

\section{UVOD}

Svetska ekonomska kriza ponovo je u prvi plan stavila značaj upravljanja sistemskim rizikom. Kako obezbediti sistem, da pogrešne odluke donete u jednoj organizaciji, ili grupi, ne dovedu do disfunkcije sistema (ili dela)? Posmatrajući dalje, relativno zaokruženi (pod)sistemi trebalo bi da deluju u skladu, stvarajući kompaktnu strukturu, bez unakrsnih smetnji. Sistem obračuna zarada, poreski sistem, sistem socijalnog osiguranja odnosno penzijski sistem u Republici Srbiji naizgled se manifestuju kao uzajamno nezavisne celine. Preispitivanju potencijalne neusklađenosti, ne treba posvećivati previše pažnje, s obzirom da iziskuje vreme i druge značajne resurse, a u stvari se ne zna šta bi se tražilo ("ukoliko radi ne treba popravljati”). Prethodni period u državnom sektoru obeležila je zastupljenost tehničkog pristupa u upravljanju rizikom (kvantifikacija promenljivih) koji je u stvari gravitirao ka reaktivnom pristupu održavanja stabilnosti. Kratkoročno posmatrano, za upravljanje rizikom potrebno je odabrati opciju koja će uz najmanja ulaganja i bez preteranog detaljisanja obaviti posao. To donekle omogućava i razvoj, uz očekivani tok promena u unutrašnjem prostoru ili okruženju. Ozbiljnje posledice mogu nastati, ukoliko promenljive izmene kretanje izvan uobičajene putanje, ili ako se pojave nove promenljive ("samo zato što nisi gledao ne znači da nije tu"). U radu ćemo nastojati da istaknemo proaktivni pristup u istraživanju nedostataka poreskog i penzijskog sistema, polazeći od metoda obračuna zarade u budžetskom sektoru, normativne uređenosti poreza i doprinosa odnosno penzijskog osiguranja i načina utvrđivanja visine penzije.

\section{BRUTO I NETO PRINCIP OBRAČUNA ZARADE}

Radi utvrđivanja formule za preračun sa neto zarade na bruto zaradu, poći će se od Korespondencija: Ljubomir Radević

\section{e-mail:} propisa kojima je uređen porez na dohodak i doprinosi za obavezno socijalno osiguranje. Zakonom o porezu na dohodak građana, u čl. 2, 15a i 16. propisano je da se mesečna bruto zarada oporezuje po stopi od 10\% uz poresku olakšicu koja trenutno iznosi 11.604 
dinara, za lice koje je radilo puno radno vreme. Zakonom o doprinosima, u čl. 3, 7, 8, 9, 13. i 44. regulisano je da se iz mesečne bruto zarade zaposlenog obračunava (bez umanjenja po osnovu poreske olakšice) doprinos za penzijsko i invalidsko osiguranje po stopi $14 \%$, doprinos za zdravstveno osiguranje po stopi 5,15\% i doprinos za slučaj nezaposlenosti 0,75\%. Zbirna stopa doprinosa na teret zaposlenog iznosi 19,9\%. Na teret poslodavca obračunava se doprinos za penzijsko i invalidsko osiguranje po stopi $12 \%$, doprinos za zdravstveno osiguranje po stopi 5,15\% i doprinos za slučaj nezaposlenosti $0,75 \%$. Ukoliko zaposleni radi na radnom mestu gde se staž osiguranja računa sa uvećanim trajanjem, zaračunavaju se dodatni doprinosi na teret poslodavca u rasponu 3,7\% - 11\% u zavisnosti od stepena uvećanja (12/14 do 12/18). Uz pretpostavku da je mesečna bruto zarada zaposlenog viša od najniže mesečne osnovice za plaćanje doprinosa ${ }^{1}$, niža od najviše mesečne osnovice za plaćanje doprinosa ${ }^{2}$, izvodi se sledeća formula za preračun bruto zarade iz neto zarade (i obrnuto):

Bruto zarada $=$ Neto zarada + Porez + Doprinosi na teret zaposlenog

Bruto zarada $=$ Neto zarada $+0,1 \times$ (Bruto zarada 11.604) $+0,199 \times$ Bruto zarada

Bruto zarada $=$ Neto zarada $+0,1 \times$ Bruto zarada $1.160,4+0,199 \times$ Bruto zarada

Bruto zarada $x(1-(0,1+0,199))=$ Neto zarada $1.160,4$

Bruto zarada $\times(1-0,299)=$ Neto zarada $-1.160,4$

Bruto zarada $\times 0,701=$ Neto $z a r a d a-1.160,4$

(6)

Bruto zarada $=($ Neto zarada $-1.160,4) / 0,701$

Neto zarada $=$ Bruto zarada $\times 0,701+1.160,4$

\section{Metode obračuna plate (zarade)}

Za obračun i isplatu plata zaposlenih kod budžetskih korisnika trenutno se primenjuje veliki broj zakonskih i podzakonskih propisa, što ima za posledicu da se obavljanje istovrsnih poslova različito vrednuje u državnim organima i institucijama. Cilj donošenja Zakona o sistemu plata zapo-

1 Zakon o doprinosima za obavezno socijalno osiguranje, čl. 36. do 42. slenih u javnom sektoru (“Službeni glasnik RS”, broj 18/16) sastoji se u uspostavljanju jedinstvene osnovice ${ }^{2}$, merila i kataloga radnih mesta, koji će ukinuti različit iznos plate za obavljanje istih poslova pod istim uslovima i rizikom. Od 2008. godine, postoje dve metode po kojima se obračunavaju plate zaposlenih kod budžetskih korisnika: metoda obračuna plate po neto osnovici i metoda obračuna plate po bruto osnovici. Metode obračuna plate, koje će se dalje razmatrati u ovom radu, nisu izmenjene novim zakonom.

Uzimajući u obzir i dodatke na platu³, formula za obračun bruto plate po osnovu neto osnovice izgledala bi:

$$
B P=\frac{\left(N_{O} \times K_{f}+N D\right)-1 \cdot 160,4}{0,701}
$$

$B P$, Bruto plata - plata zaposlenog kod budžetskog korisnika u bruto iznosu,

$N_{o}$, Neto osnovica - osnovica za obračun plate državnih službenika i nameštenika u neto iznosu,

$K_{\rho}$ Koeficijent - koeficijent prema platnom razredu i/ili platnoj grupi

ND, Neto dodaci - dodaci na platu državnog službenika ili nameštenika u neto iznosu,

\section{OBRAČUN PENZIJE}

Zakonom o penzijskom i invalidskom osiguranju u čl. 61. do 70. i čl. 78. propisan je način obračuna visine penzije (u zemlji, bez zarađene penzije iz inostranstva). U osnovi je bodovni sistem, gde se visina penzije određuje kao proizvod ličnih bodova i vrednosti opšteg boda. Lični bodovi osiguranika predstavljaju proizvod ličnog koeficijenta osiguranika i penzijskog staža. Penzijski staž se sastoji od vremena provedenog u radnom odnosu (na koji su plaćeni doprinosi), staža sa uvećanim trajanjem i posebno dodatog staža (za učesnike u ratnim dejstvima, trudnice i dr.). Lični koeficijent osiguranika dobija se tako što se zbir godišnjih ličnih koeficijenata deli sa periodom za koji su obračunati godišnji lični koeficijenti i on ne može iznositi više od 3,8. Kod obračuna ličnog koeficijenta svaka godina se računa kao 1 , svaki mesec kao 0,0833 i svaki dan kao 0,00278. Ako lice nema utvrđen staž osiguranja za celu kalendarsku godinu, godišnji lični koeficijent utvrđuje se srazmerno stažu osiguranja navršenom u toj kalendarskoj godini. Godišnji lični koeficijent računa se tako što se ukupna zarada osiguranika (zarada na radu, naknada zarade, osnovica osiguranja i ugovorena naknada na koju su plaćeni doprinosi) stavlja u odnos sa prosečnom zaradom u

2 Iako je Zakonom o sistemu plata u javnom sektoru omogućeno pojedinim budžetskim korisnicima da sami regulišu osnovicu za obračun plate (npr. lokalnim samoupravama), ista ne može biti viša od osnovice predviđene ovim zakonom, odnosno Zakonom o budžetu RS za 2016. god.

3 Dodatak na platu po osnovu minulog rada, dodatnog opterećenja, prekovremenog rada, noćnog rada itd. 
Republici za istu kalendarsku godinu iz koje je uzeta zarada. Do 2002. godine koristila se neto zarada, od 2003. se koristi bruto zarada. Godišnji lični koeficijent može iznositi najviše pet. Godišnji lični koeficijent se izračunava za svaku kalendarsku godinu u kojoj je ostvarena zarada, odnosno osnovica osiguranja, počev od 1.1.1970. godine do dana ostvarivanja prava, izuzev zarade, odnosno osnovice osiguranja ostvarene u 1993. godini (zbog hiperinflacije), i za određene kategorije zaposlenih godine pre 1996. se ne uzimaju u obzir. Ako je u pojedinoj kalendarskoj godini u periodu od 1.1.1970. godine do 31.12.2002. godine osiguranik ostvario naknadu zarade po propisima o zdravstvenom osiguranju, za period primanja naknade zarade, iznos naknade se izračunava na osnovu ličnog koeficijenta po jednom času rada za period za koji je ostvarena zarada i množi se brojem časova provedenih na bolovanju u svakoj kalendarskoj godini u kojoj je ostvarena naknada po propisima o zdravstvenom osiguranju (osnov za utvrđivanje naknade po propisima o zdravstvenom osiguranju po jednom času je isti za sve godine u kojima je ona ostvarena). Lični koeficijent na radu po satu izračunava se tako što se zbir godišnjih ličnih koeficijenata na radu deli sa ukupnim brojem sati provedenih na radu (u periodu 1970 - 2002). Godišnji lični koeficijent na bolovanju računa se tako što se lični koeficijent na radu po satu množi brojem sati provedenih na bolovanju u svakoj kalendarskoj godini za koje je ostvarena naknada zarade po propisima o zdravstvenom osiguranju.

Treba imati u vidu da se od 1.1.2003. godine u prijavu M4, pa samim tim i u bazu matične evidencije unosi nominalni iznos naknade koju osiguranik ostvari po propisima o zdrav- stvenom osiguranju i za vreme porodiljskog odsustva, pa se od 1.1.2003. godine iznos naknade sabira sa zaradom i tako se izračuna koeficijent. Godišnji lični koeficijent izračunava se sabiranjem godišnjeg ličnog koeficijenta provedenog na radu i godišnjeg ličnog koeficijenta na bolovanju za svaku kalendarsku godinu (za period od 1.1.1970. do 31.12.2002. godine). Penzijski staž koji se uzima za utvrđivanje ličnih bodova može iznositi najviše 45 godina, $s$ tim da se godina računa kao 1 , mesec kao 0,0833 i dan kao 0,00278. Kao jedan mesec računa se kalendarski mesec odnosno 30 dana. Vrednost opšteg boda od 12.2015. godine iznosi 724,66 dinara. Osiguraniku za koga u matičnoj evidenciji nisu utvrđeni podaci o zaradi, naknadi zarade, odnosno osnovici osiguranja za pojedine kalendarske godine, za izračunavanje godišnjeg ličnog koeficijenta uzima se period 1970 - 1992. prosečna godišnja neto zarada u Republici Srbiji; za period 1994 - 1998. godine iznos garantovane zarade; za period od 1. januara 1999. godine do 31. avgusta 2004. godine iznos najniže osnovice osiguranja za I i II stepen stručnosti; i za period od 1. septembra 2004. godine - iznos najniže mesečne osnovice za plaćanje doprinosa.

\section{PRIMER OBRAČUNA PENZIJE}

U nastavku je dat primer obračuna penzije, za osiguranika koji je počeo da radi 10.04.1979. godine, a ispunio uslov za starosnu penziju 05.07.2015. godine, s tim da je ostvarivao i dodatni staž osiguranja sa uvećanim trajanjem 12/16, te mu ukupan penzijski staž iznosi preko 45 godina.

Tabela 1. Primer obračuna penzije

\begin{tabular}{|c|c|c|c|c|c|c|c|c|c|c|c|c|}
\hline godina & $\begin{array}{l}\text { pros. } \\
\text { god. zar. }\end{array}$ & $\begin{array}{l}\text { obrač. } \\
\text { osn. }\end{array}$ & m.r. & d. $r$. & s.r. & s.b. & zarada & $\begin{array}{c}\text { ug. } \\
\text { naknada }\end{array}$ & $\begin{array}{l}\text { nakn. } \\
\text { bolov. }\end{array}$ & $\begin{array}{c}\text { god. lič. koef. } \\
\text { Za rad }\end{array}$ & $\begin{array}{c}\text { lični } \\
\text { koef.bol }\end{array}$ & $\begin{array}{c}\text { god. lič. } \\
\text { koef. }\end{array}$ \\
\hline 1979. & 69.912 & 44.847 & 7 & 21 & 1428 & & $51.608,00$ & & & 1,150753 & 0,000000 & 1,150753 \\
\hline 1980. & 83.604 & 83.604 & 12 & & 2096 & & $120.844,00$ & & & 1,445433 & 0,000000 & 1,445433 \\
\hline 1981. & 112.260 & 112.260 & 12 & & 1906 & 182 & $157.206,00$ & & & 1,400374 & 0,151372 & 1,551746 \\
\hline 1982. & 143.016 & 143.016 & 12 & & 2088 & & $232.236,00$ & & & 1,623846 & 0,000000 & 1,623846 \\
\hline 1983. & 181.932 & 181.932 & 12 & & 2080 & & $289.175,00$ & & & 1,589467 & 0,000000 & 1,589467 \\
\hline 1984. & 260.616 & 260.616 & 12 & & 2053 & 35 & $401.193,00$ & & & 1,539403 & 0,029110 & 1,568513 \\
\hline 1985. & 454.080 & 454.080 & 12 & & 1712 & 376 & $661.887,00$ & & & 1,457644 & 0,312725 & 1,770369 \\
\hline 1986. & 924.528 & 924.528 & 12 & & 86 & 2002 & $106.030,00$ & & & 0,114686 & 1,665092 & 1,779777 \\
\hline 1987. & 1.854 .228 & 1.854 .228 & 12 & & 1304 & 784 & $2.030 .779,00$ & & & 1,095215 & 0,652064 & 1,747279 \\
\hline 1988. & 5.094 .636 & 5.094 .636 & 12 & & 2018 & 70 & $7.252 .948,00$ & & & 1,423644 & 0,058220 & 1,481864 \\
\hline 1989. & 91.701 .372 & 91.701 .372 & 12 & & 2080 & & $1.905 .370,00$ & & & 0,020778 & 0,000000 & 0,020778 \\
\hline 1990. & 48.480 & 48.480 & 12 & & 2004 & 84 & $108.226,60$ & & & 2,232397 & 0,069864 & 2,302261 \\
\hline 1991. & 101.688 & 101.688 & 12 & & 2053 & 35 & $177.839,70$ & & & 1,748876 & 0,029110 & 1,777986 \\
\hline 1992. & 472.668 & 472.668 & 12 & & 2019 & 77 & $923.297,00$ & & & 1,953373 & 0,064042 & 2,017415 \\
\hline 1993. & & 0 & 0 & & & & & & & 0,000000 & 0,000000 & 0,000000 \\
\hline 1994. & 1.980 & 1.980 & 12 & & 1848 & 232 & $2.814,57$ & & & 1,421500 & 0,192958 & 1,614458 \\
\hline 1995. & 4.116 & 4.116 & 12 & & 1928 & 152 & $6.178,42$ & & & 1,501074 & 0,126421 & 1,627494 \\
\hline 1996. & 7.896 & 7.896 & 12 & & 2016 & 80 & $13.917,16$ & & & 1,762558 & 0,066537 & 1,829095 \\
\hline 1997. & 9.576 & 9.576 & 12 & & 1984 & 104 & $20.897,44$ & & & 2,182272 & 0,086498 & 2,268771 \\
\hline 1998. & 12.624 & 12.624 & 12 & & 1928 & 160 & $23.505,56$ & & & 1,861974 & 0,133074 & 1,995048 \\
\hline
\end{tabular}




\begin{tabular}{|c|c|c|c|c|c|c|c|c|c|c|c|c|}
\hline godina & $\begin{array}{l}\text { pros. } \\
\text { god. zar. }\end{array}$ & $\begin{array}{l}\text { obrač. } \\
\text { osn. }\end{array}$ & m.r. & d. r. & s.r. & s.b. & zarada & $\begin{array}{c}\text { ug. } \\
\text { naknada }\end{array}$ & $\begin{array}{l}\text { nakn. } \\
\text { bolov. }\end{array}$ & $\begin{array}{c}\text { god. lič. koef. } \\
\text { Za rad }\end{array}$ & $\begin{array}{c}\text { lični } \\
\text { koef.bol }\end{array}$ & $\begin{array}{l}\text { god. lič. } \\
\text { koef. }\end{array}$ \\
\hline 1999. & 15.132 & 15.132 & 12 & & 2048 & 40 & $26.953,39$ & & & 1,781218 & 0,033269 & 1,814487 \\
\hline 2000. & 28.668 & 28.668 & 12 & & 2048 & 32 & $80.326,30$ & & & 2,801950 & 0,026615 & 2,828565 \\
\hline 2001. & 70.080 & 70.080 & 12 & & 2088 & & $37.651,72$ & & & 1,964208 & 0,000000 & 1,964208 \\
\hline 2002. & 110.496 & 110.496 & 12 & & 2088 & & $77.941,74$ & & & 1,610391 & 0,000000 & 1,610391 \\
\hline 2003. & 199.344 & 199.344 & 12 & & & & $13.992,08$ & & & 1,575127 & & 1,575127 \\
\hline 2004. & 246.660 & 246.660 & 12 & & & & $75.882,99$ & & & 1,523891 & & 1,523891 \\
\hline 2005. & 306.168 & 306.168 & 12 & & & & $24.191,71$ & & & 1,385487 & & 1,385487 \\
\hline 2006. & 380.940 & 380.940 & 12 & & & & $82.105,90$ & & & 1,265569 & & 1,265569 \\
\hline 2007. & 464.928 & 464.928 & 12 & & & & $42.118,04$ & $23.333,45$ & & 1,216213 & & 1,216213 \\
\hline 2008. & 548.088 & 548.088 & 12 & & & & $73.964,25$ & $56.487,98$ & & 1,515180 & & 1,515180 \\
\hline 2009. & 529.764 & 529.764 & 12 & & & & $54.756,95$ & & $45.698,35$ & 1,699729 & & 1,699729 \\
\hline 2010. & 569.400 & 569.400 & 12 & & & & $24.323,37$ & & & 1,623329 & & 1,623329 \\
\hline 2011. & 632.796 & 632.796 & 12 & & & & $017.978,24$ & & & 1,608699 & & 1,608699 \\
\hline 2012. & 689.160 & 689.160 & 12 & & & & $111.633,11$ & & & 1,613026 & & 1,613026 \\
\hline 2013. & 728.496 & 728.496 & 12 & & & & $205.287,98$ & & & 1,654488 & & 1,654488 \\
\hline 2014. & 737.112 & 737.112 & 12 & & & & $298.942,85$ & & & 1,762206 & & 1,762206 \\
\hline 2015. & 733.740 & 376.922 & 6 & 5 & & & $57.039,09$ & & & 1,477862 & & 1,477862 \\
\hline ukupno: & \multicolumn{2}{|l|}{421} & 26 & \multicolumn{2}{|l|}{42.903} & 4.445 & \multicolumn{2}{|c|}{ zbir koeficijenata: } & \multicolumn{2}{|c|}{55,603842} & 3,696970 & 59,300811 \\
\hline & & $\mathrm{gg}$ & $\mathrm{mm}$ & $\mathrm{dd}$ & koef. & staž & & lič. koef. & 1,686812 & & dnev.ind & \\
\hline & obrač.staž & 35 & 1 & 26 & ob.koef & 35,155556 & & lič.bod & 75,906538 & & 0,00278 & \\
\hline & pen.staž & 46 & 10 & 15 & p.koef & 45,000000 & & opšti b. & 724,66 & & mes. ind. & \\
\hline & & & & & & & & penzija & $55.006,43$ & & 0,0833 & \\
\hline
\end{tabular}

\begin{tabular}{|c|c|}
\hline godina & godina na koju se odnosi prosečna godišnja zarada, odnosno zarada/naknada za osiguranika \\
\hline pros. god. zar. & prosečna godišnja zarada (do 2002. godine u neto iznosu, od 2003. godine u bruto iznosu tj. zbir neto iznosa, poreza i doprinosa na teret zaposlenog) \\
\hline obrač.osn. & $\begin{array}{l}\text { srazmeran iznos prosečne zarade za odnosnu godinu (ukoliko je period kraći od } 12 \text { meseci, prosečna godišnja zarada izračunava se srazmerno za dati } \\
\text { period) (m.r. x mes. ind. x pros. god. zar. + d.r. x dnev. ind. x pros. god. zar) }\end{array}$ \\
\hline m.r. & broj meseci koje je lice ostvarilo za posmatrani period \\
\hline d. r. & broj dana rada (upisuje se ako je ako je m.r. niže od 12 meseci) \\
\hline s.r. & godišnji broj sati rada (zbir sati rada i sati bolovanja treba da odgovara godišnjem fondu sati rada, za lice koje radi puno radno vreme) \\
\hline s.b. & godišnji broj sati odsustva sa posla za vreme privremene sprečenosti za rad \\
\hline zarada & $\begin{array}{l}\text { upisuje se ostvarena zarada za posmatrani period (do 2002. godine u neto iznosu, od 2003. godine u bruto iznosu tj zbir neto iznosa, poreza i doprino- } \\
\text { sa na teret zaposlenog) }\end{array}$ \\
\hline ug. naknada & upisuje se ostvarena naknada (koja ima tretman zarade) za posmatrani period (do 2002. godine u neto iznosu, od 2003. godine u bruto iznosu \\
\hline nakn. bolov. & upisuje se ostvarena naknada za vreme sprečenosti za rad od 2003. godine u bruto iznosu \\
\hline god. lič. koef. rad & $\begin{array}{l}\text { godišnji lični koeficijent na radu - računao se do 2002. godine, tako što se zbir zarade i ugovorene naknade (na koju su plaćeni doprinosi) stavljao } \\
\text { u odnos sa prosečnom zaradom u Republici za istu kalendarsku godinu iz koje je uzeta zarada. Od 2003. godine zbir zarade, ugovorene naknade i } \\
\text { naknade za bolovanje stavlja se u odnos sa prosečnom zaradom, što predstavlja godišnji lični koeficijent. }\end{array}$ \\
\hline l.koef.bol & $\begin{array}{l}\text { godišnji lični koeficijent na bolovanju računao se od 1970. do 2002. tako što se lični koeficijent na radu po satu množio brojem sati provedenih na } \\
\text { bolovanju (zbir lič. koef. rad. / zbir s.r. od } 1970 \text { do 2002) x (s. b. za posmatranu godinu) }\end{array}$ \\
\hline god. lič. koef. & $\begin{array}{l}\text { godišnji lični koeficijent. Do kraja 2002. godine, računao se sabiranjem godišnjeg ličnog koeficijenta provedenog na radu i godišnjeg ličnog koefici- } \\
\text { jenta na bolovanju za svaku kalendarsku godinu (lič. koef. rad + l.koef.bol). Od 2003. računa se tako što se zbir zarade, ugovorene naknade, osnovice } \\
\text { osiguranja i naknade za bolovanje stavlja u odnos sa prosečnom zaradom. Može najviše iznositi pet za jednu godinu. }\end{array}$ \\
\hline obrač.staž & staž na koji se odnosi zarada, ugovorena naknada i naknada za bolovanje, odnosno osnovica osiguranja \\
\hline pen.staž & penzijski staž (efektivni staž, beneficirani staž, poseban staž). Može najviše iznositi 45 \\
\hline lič. koef. & $\begin{array}{l}\text { Lični koeficijent osiguranika. Dobija se tako što se zbir godišnjih ličnih koeficijenata (god. lič. koef) deli sa periodom (obrač.staž) za koji su obračunati } \\
\text { godišnji lični koeficijenti. Ne može iznositi više od } 3,8\end{array}$ \\
\hline lič.bod & Lični bodovi osiguranika predstavljaju proizvod ličnog koeficijenta (lič. koef.) osiguranika i penzijskog staža (pen. staž) \\
\hline opšti b. & vrednost opšteg boda iznosi od decembra 2015. godine 724,66 dinara (“Službeni glasnik RS”, br. 6/2016 i 7/2016) \\
\hline dnev.ind & računanje jednog dana \\
\hline mes. ind. & računanje jednog meseca \\
\hline penzija & $\begin{array}{l}\text { vrednost penzije obračunate po Zakonu o penziji, bez umanjenja prema Zakonu o privremenom uređivanju načina isplate penzija („Službeni glasnik } \\
\text { RS“, br. 116/2014) }\end{array}$ \\
\hline
\end{tabular}

Prema propisima i prikazanom primeru, može se zaključiti da rast individualne zarade ne predstavlja dovoljni uslov da se licu uvećava penzijski osnov nego zavisi i od trenda rasta prosečne zarade. Ukoliko godišnja zarada lica raste više od godišnje prosečne zarade, licu će se uvećavati penzijsko osiguranje i obrnuto. U situaciji kada se kod budžetskih korisnika isti poslovi različito vrednuju, jedna kategorija lica će primati veće penzijsko osiguranje ne samo zbog svoje veće zarade, nego i zbog sporijeg rasta prosečne zarade usled niže zarade druge kategorije lica, doduše u materijalnom značaju, samo ako je masa zarada druge kategorije lica dovoljno velika, da znatno utiče na sporiji rast prosečne zarade. 


\section{TROŠKOVI POREZA I DOPRINOSA NA PLATU}

Radi analize poreskog uticaja, razmatraće se uporedne tabele obračuna osnovne plate (bez dodataka) po neto odnosno bruto osnovici, sa bruto platom koja sadrži neto platu, porez i doprinose na teret zaposlenog. Promene stopa doprinosa na teret poslodavca direktno utiču na rast ili pad ukupnog troška plate nezavisno od metode obračuna plate tako da nije potrebno posebno pratiti promene ove kategorije doprinosa (s obzirom da je učinak na trošak doprinosa na teret poslodavca srazmeran promeni). U prvoj tabeli, poći će se od metode obračuna plate po neto osnovici, na osnovu koje će se odrediti početni iznos neto odnosno bruto plate, dok će se u drugoj tabeli poći od bruto osnovice, koja će se odrediti u iznosu koji će dovesti do bruto odnosno neto plate u istom iznosu kao u slučaju obračuna po neto osnovici. Neto odnosno bruto osnovica se neće menjati kroz primere, radi usmeravanja pažnje na posledice promena stopa poreza i doprinosa na teret zaposlenog, koje su predmet analize.

Tabela 2. Obračun plate po neto osnovici bez poreske olakšice

\begin{tabular}{|c|c|c|}
\hline Red. br. & Naziv & Iznos \\
\hline 1 & Neto osnovica & $17.101,29$ \\
\hline 2 & Koeficijent & 5,57 \\
\hline 3 & Poreska olakšica & 0,00 \\
\hline 4 & Stopa poreza na dohodak & $10,00 \%$ \\
\hline 5 & Stopa doprinosa za PIO na teret zaposlenog & $14,00 \%$ \\
\hline 6 & $\begin{array}{l}\text { Stopa doprinosa za zdr.osig. na teret } \\
\text { zaposlenog }\end{array}$ & $5,15 \%$ \\
\hline 7 & $\begin{array}{l}\text { Stopa doprinosa za osig. za sl. nez. na teret } \\
\text { zaposlenog }\end{array}$ & $0,75 \%$ \\
\hline 8 & $\begin{array}{l}\text { Koeficijent za preračun } \\
1 \text { - (red. br. } 4 .+ \text { red. br. } 5 .+ \text { red. br. } 6 \text { + red. } \\
\text { br. } 7 \text { ) }\end{array}$ & 0,701 \\
\hline 9 & Neto plata (red. br. 1 x red. br. 2) & $95.254,19$ \\
\hline 10 & $\begin{array}{l}\text { Bruto plata ((red. br. } 9 \text { - red. br. } 3 \times \text { red. } \\
\text { br. 4) / red. br. } 8)\end{array}$ & $135.883,29$ \\
\hline 11 & Porez (red. br. 10 - red. br. 3) x (red. br. 4.) & $13.588,33$ \\
\hline 12 & $\begin{array}{l}\text { Doprinos za PIO na teret zaposlenog (red. } \\
\text { br. } 5 \text { x red. br. 10) }\end{array}$ & $19.023,66$ \\
\hline 13 & $\begin{array}{l}\text { Doprinos za zdr.osig. na teret zaposlenog } \\
\text { (red. br. } 6 \text { x red. br. 10) }\end{array}$ & $6.997,99$ \\
\hline 14 & $\begin{array}{l}\text { Doprinos za osig. za sl. nez. na teret zapos- } \\
\text { lenog (red. br. } 7 \text { x red. br. 10) }\end{array}$ & $1.019,12$ \\
\hline
\end{tabular}

Tabela 3. Obračun plate po bruto osnovici bez poreske olakšice

\begin{tabular}{clr}
\hline Red. br. & \multicolumn{1}{c}{ Naziv } & \multicolumn{1}{c}{ Iznos } \\
\hline $\mathbf{1}$ & Bruto osnovica (neto osnovica / 0,701) & $\mathbf{2 4 . 3 9 5 , 5 6}$ \\
\hline 2 & Koeficijent & 5,57 \\
\hline 3 & Poreska olakšica & 0,00
\end{tabular}

\begin{tabular}{|c|c|c|}
\hline Red. br. & Naziv & Iznos \\
\hline 4 & Stopa poreza na dohodak & $10,00 \%$ \\
\hline 5 & $\begin{array}{l}\text { Stopa doprinosa za PIO na teret zapos- } \\
\text { lenog }\end{array}$ & $14,00 \%$ \\
\hline 6 & $\begin{array}{l}\text { Stopa doprinosa za zdr.osig. na teret } \\
\text { zaposlenog }\end{array}$ & $5,15 \%$ \\
\hline 7 & $\begin{array}{l}\text { Stopa doprinosa za osig. za sl. nez. na } \\
\text { teret zaposlenog }\end{array}$ & $0,75 \%$ \\
\hline 8 & $\begin{array}{l}\text { Koeficijent za preračun } \\
1 \text { - (red. br. } 4 .+ \text { red. br. } 5 .+ \text { red. br. } 6+ \\
\text { red. br. } 7 \text { ) }\end{array}$ & 0,701 \\
\hline 9 & Bruto plata (red. br. $1 \times$ red. br. 2) & $135.883,29$ \\
\hline 10 & $\begin{array}{l}\text { Neto plata (red. br. } 9 \times \text { red. br. } 8+\text { red. } \\
\text { br. } 3 \times \text { red. br. } 4 \text { ) }\end{array}$ & $95.254,19$ \\
\hline 11 & Porez (red. br. 9 - red. br. 3) x (red. br. 4.) & $13.588,33$ \\
\hline 12 & $\begin{array}{l}\text { Doprinos za PIO na teret zaposlenog } \\
\text { (red. br. } 5 \text { x red. br. 9) }\end{array}$ & $19.023,66$ \\
\hline 13 & $\begin{array}{l}\text { Doprinos za zdr. osig. na teret zaposlenog } \\
\text { (red. br. } 6 \text { x red. br. 9) }\end{array}$ & $6.997,99$ \\
\hline 14 & $\begin{array}{l}\text { Doprinos za osig. za sl. nez. na teret } \\
\text { zaposlenog (red. br. } 7 \text { x red. br. 9) }\end{array}$ & $1.019,12$ \\
\hline
\end{tabular}

Prve dve tabele poslužiće kao bazni primeri po kojima će se upoređivati ishodi promena u narednim tabelama, usled promene stopa doprinosa i poreza. U nastavku, prvo će se razmatrati promene stope komponente doprinosa.

\section{Uticaj promene stope doprinosa na teret zaposlenog}

Tabela 4. Obračun plate po neto osnovici bez poreske olakšice, sa uvećanom stopom doprinosa za penzijsko i invalidsko osiguranje na teret zaposlenog

\begin{tabular}{|c|c|c|}
\hline Red. br. & Naziv & Iznos \\
\hline 1 & Neto osnovica & $17.101,29$ \\
\hline 2 & Koeficijent & 5,57 \\
\hline 3 & Poreska olakšica & 0,00 \\
\hline 4 & Stopa poreza na dohodak & $10,00 \%$ \\
\hline 5 & $\begin{array}{l}\text { Stopa doprinosa za PIO na teret } \\
\text { zaposlenog }\end{array}$ & $15,00 \% \uparrow$ \\
\hline 6 & $\begin{array}{l}\text { Stopa doprinosa za zdr.osig. na teret } \\
\text { zaposlenog }\end{array}$ & $5,15 \%$ \\
\hline 7 & $\begin{array}{l}\text { Stopa doprinosa za osig. za sl. nez. na } \\
\text { teret zaposlenog }\end{array}$ & $0,75 \%$ \\
\hline 8 & $\begin{array}{l}\text { Koeficijent za preračun } \\
1 \text { - (red. br. } 4 .+ \text { red. br. } 5 .+ \text { red. br. } 6+ \\
\text { red. br. } 7 \text { ) }\end{array}$ & 0,691 \\
\hline 9 & Neto plata (red. br. 1 x red. br. 2) & $95.254,19$ \\
\hline 10 & $\begin{array}{l}\text { Bruto plata ((red. br. } 9 \text { - red. br. } 3 \times \\
\text { red. br. } 4) \text { / red. br. } 8)\end{array}$ & $137.849,76 \uparrow$ \\
\hline 11 & $\begin{array}{l}\text { Porez (red. br. } 10 \text { - red. br. 3) x (red. } \\
\text { br. 4.) }\end{array}$ & $13.784,98 \uparrow$ \\
\hline 12 & $\begin{array}{l}\text { Doprinos za PIO na teret zaposlenog } \\
\text { (red. br. } 5 \text { x red. br. 10) }\end{array}$ & $20.677,46 \uparrow$ \\
\hline 13 & $\begin{array}{l}\text { Doprinos za zdr.osig. na teret zaposle- } \\
\text { nog (red. br. } 6 \text { x red. br. 10) }\end{array}$ & $7.099,26 \uparrow$ \\
\hline 14 & $\begin{array}{l}\text { Doprinos za osig. za sl. nez. na teret } \\
\text { zaposlenog (red. br. } 7 \text { x red. br. 10) }\end{array}$ & $1.033,87 \uparrow$ \\
\hline
\end{tabular}


Tabela 5. Obračun plate po neto osnovici bez poreske olakšice, sa smanjenom stopom doprinosa za penzijsko i invalidsko osiguranje na teret zaposlenog

\begin{tabular}{|c|c|c|}
\hline Red. br. & Naziv & Iznos \\
\hline 1 & Neto osnovica & $17.101,29$ \\
\hline 2 & Koeficijent & 5,57 \\
\hline 3 & Poreska olakšica & 0,00 \\
\hline 4 & Stopa poreza na dohodak & $10,00 \%$ \\
\hline 5 & $\begin{array}{l}\text { Stopa doprinosa za PIO na teret } \\
\text { zaposlenog }\end{array}$ & $13,00 \% \downarrow$ \\
\hline 6 & $\begin{array}{l}\text { Stopa doprinosa za zdr.osig. na teret } \\
\text { zaposlenog }\end{array}$ & $5,15 \%$ \\
\hline 7 & $\begin{array}{l}\text { Stopa doprinosa za osig. za sl. nez. na } \\
\text { teret zaposlenog }\end{array}$ & $0,75 \%$ \\
\hline 8 & $\begin{array}{l}\text { Koeficijent za preračun } \\
1 \text { - (red. br. } 4 .+ \text { red. br. } 5 .+ \text { red. br. } 6+ \\
\text { red. br. } 7 \text { ) }\end{array}$ & 0,711 \\
\hline 9 & Neto plata (red. br. 1 x red. br. 2) & $95.254,19$ \\
\hline 10 & $\begin{array}{l}\text { Bruto plata ((red. br. } 9 \text { - red. br. } 3 \text { x } \\
\text { red. br. } 4) / \text { red. br. } 8)\end{array}$ & $133.972,13 \downarrow$ \\
\hline 11 & $\begin{array}{l}\text { Porez (red. br. } 10 \text { - red. br. 3) x (red. } \\
\text { br. 4.) }\end{array}$ & $13.397,21 \downarrow$ \\
\hline 12 & $\begin{array}{l}\text { Doprinos za PIO na teret zaposlenog } \\
\text { (red. br. } 5 \text { x red. br. 10) }\end{array}$ & $17.416,38 \downarrow$ \\
\hline 13 & $\begin{array}{l}\text { Doprinos za zdr.osig. na teret zapos- } \\
\text { lenog (red. br. } 6 \text { x red. br. 10) }\end{array}$ & $6.899,56 \downarrow$ \\
\hline 14 & $\begin{array}{l}\text { Doprinos za osig. za sl. nez. na teret } \\
\text { zaposlenog (red. br. } 7 \text { x red. br. 10) }\end{array}$ & $1.004,79 \downarrow$ \\
\hline
\end{tabular}

$\mathrm{Na}$ osnovu poređenja baznih rezultata i rezultata iz gornjih tabela, kod obračuna plate po neto osnovici, promena zbirne stope doprinosa na teret zaposlenog ${ }^{4}$ uz nepromenjenu visinu poreske stope i poreske olakšice ne menja visinu neto plate, a direktno utiče na kretanje visine bruto plate odnosno, na rast/smanjenje troškova poreza i doprinosa i ukupnog troška plate.

Tabela 6. Obračun plate po bruto osnovici bez poreske olakšice, sa uvećanom stopom doprinosa za penzijsko i invalidsko osiguranje na teret zaposlenog

\begin{tabular}{clr}
\hline Red. br. & \multicolumn{1}{c}{ Naziv } & \multicolumn{2}{c}{ Iznos } \\
\hline $\mathbf{1}$ & Bruto osnovica & $\mathbf{2 4 . 3 9 5 , 5 6}$ \\
\hline 2 & Koeficijent & 5,57 \\
\hline 3 & Poreska olakšica & 0,00 \\
\hline 4 & Stopa poreza na dohodak & $\mathbf{1 0 , 0 0 \%}$ \\
\hline $\mathbf{5}$ & $\begin{array}{l}\text { Stopa doprinosa za PIO na teret } \\
\text { zaposlenog }\end{array}$ & $\mathbf{1 5 , 0 0 \%} \uparrow$ \\
\hline 6 & $\begin{array}{l}\text { Stopa doprinosa za zdr.osig. na } \\
\text { teret zaposlenog }\end{array}$ & $0,75 \%$ \\
\hline 7 & $\begin{array}{l}\text { Stopa doprinosa za osig. za sl. nez. } \\
\text { na teret zaposlenog }\end{array}$ & $\begin{array}{l}\text { Koeficijent za preračun } \\
\text { 1 - (red. br. 4. + red. br. 5. + red. br. }\end{array}$ \\
\hline 6 + red. br. 7)
\end{tabular}

4 U situaciji kada se stopa jedne komponente doprinosa uveća za odredeni procenat a stopa druge komponente umanji za isti procenat, zbirna stopa doprinosa ostaje nepromenjena.

\begin{tabular}{clr}
\hline Red. br. & \multicolumn{1}{c}{ Naziv } & \multicolumn{1}{c}{ Iznos } \\
\hline 9 & Bruto plata (red. br. 1 x red. br. 2) & $135.883,29$ \\
\hline $\mathbf{1 0}$ & $\begin{array}{l}\text { Neto plata (red. br. 9 x red. br. 8 + } \\
\text { red. br. 3 x red. br. 4) }\end{array}$ & $\mathbf{9 3 . 8 9 5 , 3 5 \downarrow}$ \\
\hline 11 & $\begin{array}{l}\text { Porez (red. br. 9 - red. br. 3) x (red. } \\
\text { br. 4.) }\end{array}$ & $13.588,33$ \\
\hline $\mathbf{1 2}$ & $\begin{array}{l}\text { Doprinos za PIO na teret zaposle- } \\
\text { nog (red. br. 5 x red. br. 9) }\end{array}$ & $\mathbf{2 0 . 3 8 2 , 4 9 \uparrow}$ \\
\hline 13 & $\begin{array}{l}\text { Doprinos za zdr.osig. na teret za- } \\
\text { poslenog (red. br. 6 x red. br. 9) }\end{array}$ & $\mathbf{6 . 9 9 7 , 9 9}$ \\
\hline 14 & $\begin{array}{l}\text { Doprinos za osig. za sl. nez. na teret } \\
\text { zaposlenog (red. br. 7 x red. br. 9) }\end{array}$ & $1.019,12$ \\
\hline
\end{tabular}

Tabela 7. Obračun plate po bruto osnovici bez poreske olakšice, sa umanjenom stopom doprinosa za penzijsko i invalidsko osiguranje

\begin{tabular}{|c|c|c|}
\hline Red. br. & Naziv & Iznos \\
\hline 1 & Bruto osnovica & $24.395,56$ \\
\hline 2 & Koeficijent & 5,57 \\
\hline 3 & Poreska olakšica & 0,00 \\
\hline 4 & Stopa poreza na dohodak & $10,00 \%$ \\
\hline 5 & $\begin{array}{l}\text { Stopa doprinosa za PIO na teret } \\
\text { zaposlenog }\end{array}$ & $13,00 \% \downarrow$ \\
\hline 6 & $\begin{array}{l}\text { Stopa doprinosa za zdr.osig. na teret } \\
\text { zaposlenog }\end{array}$ & $5,15 \%$ \\
\hline 7 & $\begin{array}{l}\text { Stopa doprinosa za osig. za sl. nez. } \\
\text { na teret zaposlenog }\end{array}$ & $0,75 \%$ \\
\hline 8 & $\begin{array}{l}\text { Koeficijent za preračun } \\
1 \text { - (red. br. } 4 .+ \text { red. br. } 5 .+ \text { red. br. } \\
6+\text { red. br. } 7)\end{array}$ & 0,711 \\
\hline 9 & Bruto plata (red. br. $1 \mathrm{x}$ red. br. 2 ) & $135.883,29$ \\
\hline 10 & $\begin{array}{l}\text { Neto plata (red. br. } 9 \times \text { red. br. } 8+ \\
\text { red. br. } 3 \times \text { red. br. } 4)\end{array}$ & $96.613,02 \uparrow$ \\
\hline 11 & $\begin{array}{l}\text { Porez (red. br. } 9 \text { - red. br. 3) x (red. } \\
\text { br. 4.) }\end{array}$ & $13.588,33$ \\
\hline 12 & $\begin{array}{l}\text { Doprinos za PIO na teret zaposle- } \\
\text { nog (red. br. } 5 \text { x red. br. 9) }\end{array}$ & $17.664,83 \downarrow$ \\
\hline 13 & $\begin{array}{l}\text { Doprinos za zdr.osig. na teret zapos- } \\
\text { lenog (red. br. } 6 \text { x red. br. } 9 \text { ) }\end{array}$ & $6.997,99$ \\
\hline 14 & $\begin{array}{l}\text { Doprinos za osig. za sl. nez. na teret } \\
\text { zaposlenog (red. br. } 7 \text { x red. br. 9) }\end{array}$ & $1.019,12$ \\
\hline
\end{tabular}

$\mathrm{Na}$ osnovu gornjih rezultata može se uočiti, kod metode obračuna plate po bruto osnovici, promena zbirne stope doprinosa na teret zaposlenog uz nepromenjenu visinu poreske stope i poreske olakšice ne menja bruto platu niti ukupan trošak plate, ali uvećanjem/smanjenjem stope bilo koje komponente doprinosa dolazi do uvećanja/smanjenja iznosa troška te komponente doprinosa i smanjenja/uvećanja neto plate za isti iznos razlike (sa suprotnim predznakom).

Posmatrano sa aspekta trenutnog uređenja sistema penzijskog osiguranja Republike Srbije, obračun penzijskog osnova srazmeran je odnosu zarade zaposlenog prema prosečnoj zaradi izvedenoj iz mase zarada svih radno angažovanih lica u privrednim i vanprivrednim delatnostima (tj. od zarada/plata po bruto ili neto osnovici) za određeni period (uobičajeno za 
godinu dana), u situacijama kada se zbirna stopa doprinosa na teret zaposlenog uvećava (dok stopa poreza i poreska olakšica ostaju nepromenjene), lica koja primaju zaradu/platu po neto osnovici ostvaruju veće pravo na penzijsko osiguranje u odnosu na lica koja primaju zaradu/platu po bruto osnovici, pošto im uz istu neto platu bruto zarada/plata raste, dok drugima stagnira uz manju neto platu. Kada zbirna stopa doprinosa na teret zaposlenog opada (poreska stopa i poreska olakšica se ne menjaju) bruto zarada/plata po neto osnovici se smanjuje utičući u svom segmentu na visinu prosečne bruto zarade, omogućujući veća prava na penzijsko osiguranje licima čija se zarada/plata obračunava po bruto osnovici.

\section{Uticaj promene poreske stope}

Tabela 8. Obračun plate po neto osnovici bez poreske olakšice, uz uvećanje poreske stope

\begin{tabular}{|c|c|c|}
\hline Red. br. & Naziv & Iznos \\
\hline 1 & Neto osnovica & $17.101,29$ \\
\hline 2 & Koeficijent & 5,57 \\
\hline 3 & Poreska olakšica & 0,00 \\
\hline 4 & Stopa poreza na dohodak & $12,00 \% \uparrow$ \\
\hline 5 & $\begin{array}{l}\text { Stopa doprinosa za PIO na teret zapos- } \\
\text { lenog }\end{array}$ & $14,00 \%$ \\
\hline 6 & $\begin{array}{l}\text { Stopa doprinosa za zdr.osig. na teret } \\
\text { zaposlenog }\end{array}$ & $5,15 \%$ \\
\hline 7 & $\begin{array}{l}\text { Stopa doprinosa za osig. za sl. nez. na } \\
\text { teret zaposlenog }\end{array}$ & $0,75 \%$ \\
\hline 8 & $\begin{array}{l}\text { Koeficijent za preračun } \\
1 \text { - (red. br. } 4 .+ \text { red. br. } 5 .+ \text { red. br. } 6+ \\
\text { red. br. } 7 \text { ) }\end{array}$ & 0,681 \\
\hline 9 & Neto plata (red. br. $1 \times$ red. br. 2 ) & $95.254,19$ \\
\hline 10 & $\begin{array}{l}\text { Bruto plata ((red. br. } 9 \text { - red. br. } 3 \text { x } \\
\text { red. br. 4) / red. br. 8) }\end{array}$ & $139.873,99 \uparrow$ \\
\hline 11 & $\begin{array}{l}\text { Porez (red. br. } 10 \text { - red. br. 3) x (red. } \\
\text { br. 4.) }\end{array}$ & $16.784,88 \uparrow$ \\
\hline 12 & $\begin{array}{l}\text { Doprinos za PIO na teret zaposlenog } \\
\text { (red. br. } 5 \text { x red. br. 10) }\end{array}$ & $19.582,36 \uparrow$ \\
\hline 13 & $\begin{array}{l}\text { Doprinos za zdr.osig. na teret zaposle- } \\
\text { nog (red. br. } 6 \text { x red. br. 10) }\end{array}$ & $7.203,51 \uparrow$ \\
\hline 14 & $\begin{array}{l}\text { Doprinos za osig. za sl. nez. na teret } \\
\text { zaposlenog (red. br. } 7 \text { x red. br. 10) }\end{array}$ & $1.049,05 \uparrow$ \\
\hline
\end{tabular}

Tabela 9. Obračun plate po neto osnovici bez poreske olakšice, uz umanjenje poreske stope

\begin{tabular}{clr}
\hline Red. br. & \multicolumn{1}{c}{ Naziv } & \multicolumn{1}{c}{ Iznos } \\
\hline $\mathbf{1}$ & Neto osnovica & $\mathbf{1 7 . 1 0 1 , 2 9}$ \\
\hline 2 & Koeficijent & 5,57 \\
\hline 3 & Poreska olakšica & 0,00 \\
\hline $\mathbf{4}$ & Stopa poreza na dohodak & $\mathbf{8 , 0 0 \% \downarrow}$ \\
\hline 5 & $\begin{array}{l}\text { Stopa doprinosa za PIO na teret } \\
\text { zaposlenog }\end{array}$ & $14,00 \%$ \\
\hline 6 & $\begin{array}{l}\text { Stopa doprinosa za zdr.osig. na teret } \\
\text { zaposlenog }\end{array}$ & $5,15 \%$ \\
\hline
\end{tabular}

\begin{tabular}{|c|c|c|}
\hline Red. br. & Naziv & Iznos \\
\hline 7 & $\begin{array}{l}\text { Stopa doprinosa za osig. za sl. nez. na } \\
\text { teret zaposlenog }\end{array}$ & $0,75 \%$ \\
\hline 8 & $\begin{array}{l}\text { Koeficijent za preračun } \\
1 \text { - (red. br. } 4 .+ \text { red. br. } 5 .+ \text { red. br. } 6 \\
\text { + red. br. } 7 \text { ) }\end{array}$ & 0,721 \\
\hline 9 & Neto plata (red. br. $1 \mathrm{x}$ red. br. 2 ) & $95.254,19$ \\
\hline 10 & $\begin{array}{l}\text { Bruto plata ((red. br. } 9 \text { - red. br. } 3 x \\
\text { red. br. 4) / red. br. 8) }\end{array}$ & $132.113,99 \downarrow$ \\
\hline 11 & $\begin{array}{l}\text { Porez (red. br. } 10 \text { - red. br. 3) x (red. } \\
\text { br. 4.) }\end{array}$ & $10.569,12 \downarrow$ \\
\hline 12 & $\begin{array}{l}\text { Doprinos za PIO na teret zaposlenog } \\
\text { (red. br. } 5 \text { x red. br. 10) }\end{array}$ & $18.495,96 \downarrow$ \\
\hline 13 & $\begin{array}{l}\text { Doprinos za zdr.osig. na teret zapos- } \\
\text { lenog (red. br. } 6 \text { x red. br. } 10 \text { ) }\end{array}$ & $6.803,87 \downarrow$ \\
\hline 14 & $\begin{array}{l}\text { Doprinos za osig. za sl. nez. na teret } \\
\text { zaposlenog (red. br. } 7 \text { x red. br. 10) }\end{array}$ & $990,85 \downarrow$ \\
\hline
\end{tabular}

Kao što se moglo zaključiti i u slučaju promene stope doprinosa na teret zaposlenog, promena stope poreza (uz nepromenjenu zbirnu stopu doprinosa na teret zaposlenog i nepromenjenu visinu poreske olakšice) kod metode obračuna plate po neto osnovici direktno utiče na kretanje bruto plate odnosno troškova poreza i doprinosa, pri čemu neto plata ostaje nepromenjena.

Tabela 10. Obračun plate po bruto osnovici bez poreske olakšice, uz uvećanje poreske stope

\begin{tabular}{|c|c|c|}
\hline Red. br. & Naziv & Iznos \\
\hline 1 & Bruto osnovica & $24.395,56$ \\
\hline 2 & Koeficijent & 5,57 \\
\hline 3 & Poreska olakšica & 0,00 \\
\hline 4 & Stopa poreza na dohodak & $12,00 \% \uparrow$ \\
\hline 5 & $\begin{array}{l}\text { Stopa doprinosa za PIO na teret zapos- } \\
\text { lenog }\end{array}$ & $14,00 \%$ \\
\hline 6 & $\begin{array}{l}\text { Stopa doprinosa za zdr.osig. na teret } \\
\text { zaposlenog }\end{array}$ & $5,15 \%$ \\
\hline 7 & $\begin{array}{l}\text { Stopa doprinosa za osig. za sl. nez. na } \\
\text { teret zaposlenog }\end{array}$ & $0,75 \%$ \\
\hline 8 & $\begin{array}{l}\text { Koeficijent za preračun } \\
1-(\text { red. br. } 4 .+ \text { red. br. } 5 .+ \text { red. br. } 6+ \\
\text { red. br. } 7 \text { ) }\end{array}$ & 0,681 \\
\hline 9 & Bruto plata (red. br. 1 x red. br. 2) & $135.883,29$ \\
\hline 10 & $\begin{array}{l}\text { Neto plata (red. br. } 9 \times \text { red. br. } 8+\text { red. } \\
\text { br. } 3 \times \text { red. br. } 4 \text { ) }\end{array}$ & $92.536,52 \downarrow$ \\
\hline 11 & $\begin{array}{l}\text { Porez (red. br. } 9 \text { - red. br. 3) x (red. } \\
\text { br. 4.) }\end{array}$ & $16.305,99 \uparrow$ \\
\hline 12 & $\begin{array}{l}\text { Doprinos za PIO na teret zaposlenog } \\
\text { (red. br. } 5 \text { x red. br. } 9 \text { ) }\end{array}$ & $19.023,66$ \\
\hline 13 & $\begin{array}{l}\text { Doprinos za zdr.osig. na teret zaposle- } \\
\text { nog (red. br. } 6 \text { x red. br. } 9 \text { ) }\end{array}$ & $6.997,99$ \\
\hline 14 & $\begin{array}{l}\text { Doprinos za osig. za sl. nez. na teret } \\
\text { zaposlenog (red. br. } 7 \text { x red. br. 9) }\end{array}$ & $1.019,12$ \\
\hline
\end{tabular}


Tabela 11. Obračun plate po bruto osnovici bez poreske olakšice, uz umanjenje poreske stope

\begin{tabular}{|c|c|c|}
\hline Red. br. & Naziv & Iznos \\
\hline 1 & Bruto osnovica & $24.395,56$ \\
\hline 2 & Koeficijent & 5,57 \\
\hline 3 & Poreska olakšica & 0,00 \\
\hline 4 & Stopa poreza na dohodak & $8,00 \% \downarrow$ \\
\hline 5 & $\begin{array}{l}\text { Stopa doprinosa za PIO na teret zapos- } \\
\text { lenog }\end{array}$ & $14,00 \%$ \\
\hline 6 & $\begin{array}{l}\text { Stopa doprinosa za zdr.osig. na teret } \\
\text { zaposlenog }\end{array}$ & $5,15 \%$ \\
\hline 7 & $\begin{array}{l}\text { Stopa doprinosa za osig. za sl. nez. na } \\
\text { teret zaposlenog }\end{array}$ & $0,75 \%$ \\
\hline 8 & $\begin{array}{l}\text { Koeficijent za preračun } \\
1 \text { - (red. br. } 4 .+ \text { red. br. } 5 .+ \text { red. br. } 6+ \\
\text { red. br. } 7 \text { ) }\end{array}$ & 0,721 \\
\hline 9 & Bruto plata (red. br. 1 x red. br. 2) & $135.883,29$ \\
\hline 10 & $\begin{array}{l}\text { Neto plata (red. br. } 9 \times \text { red. br. } 8+\text { red. } \\
\text { br. } 3 \times \text { red. br. } 4 \text { ) }\end{array}$ & 97.971,85 $\uparrow$ \\
\hline 11 & $\begin{array}{l}\text { Porez (red. br. } 9 \text { - red. br. } 3 \text { ) x (red. br. } \\
\text { 4.) }\end{array}$ & $10.870,66 \downarrow$ \\
\hline 12 & $\begin{array}{l}\text { Doprinos za PIO na teret zaposlenog } \\
\text { (red. br. } 5 \text { x red. br. 9) }\end{array}$ & $19.023,66$ \\
\hline 13 & $\begin{array}{l}\text { Doprinos za zdr.osig. na teret zaposle- } \\
\text { nog (red. br. } 6 \text { x red. br. } 9 \text { ) }\end{array}$ & $6.997,99$ \\
\hline 14 & $\begin{array}{l}\text { Doprinos za osig. za sl. nez. na teret } \\
\text { zaposlenog (red. br. } 7 \text { x red. br. 9) }\end{array}$ & $1.019,12$ \\
\hline
\end{tabular}

Kod metode obračuna plate po bruto osnovici, promena stope poreza (uz nepromenjenu visinu zbirne stope doprinosa na teret zaposlenog i nepromenjenu visinu poreske olakšice) direktno utiče na visinu poreza, a obrnuto na visinu neto plate, za isti iznos razlike sa suprotnim predznakom (apsolutna vrednost razlike između visine poreza pre promene i visine poreza nakon promene poreske stope jednaka je vrednosti razlike kod neto plate pre i posle promene). Trošak bruto plate ostaje nepromenjen.

\section{Uticaj poreske olakšice}

Tabela 12. Obračun plate po neto osnovici sa poreskom olakšicom

\begin{tabular}{|c|c|c|}
\hline Red. br. & Naziv & Iznos \\
\hline 1 & Neto osnovica & $17.101,29$ \\
\hline 2 & Koeficijent & 5,57 \\
\hline 3 & Poreska olakšica & $11.604,00$ \\
\hline 4 & Stopa poreza na dohodak & $10,00 \%$ \\
\hline 5 & $\begin{array}{l}\text { Stopa doprinosa za PIO na teret zapos- } \\
\text { lenog }\end{array}$ & $14,00 \%$ \\
\hline 6 & $\begin{array}{l}\text { Stopa doprinosa za zdr.osig. na teret } \\
\text { zaposlenog }\end{array}$ & $5,15 \%$ \\
\hline 7 & $\begin{array}{l}\text { Stopa doprinosa za osig. za sl. nez. na } \\
\text { teret zaposlenog }\end{array}$ & $0,75 \%$ \\
\hline
\end{tabular}

\begin{tabular}{clr}
\hline Red. br. & \multicolumn{1}{c}{ Naziv } & \multicolumn{1}{c}{ Iznos } \\
\hline 8 & $\begin{array}{l}\text { Koeficijent za preračun } \\
\text { - (red. br. 4. + red. br. 5. + red. br. 6 + } \\
\text { red. br. 7) }\end{array}$ & 0,701 \\
\hline 9 & Neto plata (red. br. 1 x red. br. 2) & $95.254,19$ \\
\hline 10 & $\begin{array}{l}\text { Bruto plata (red. br. 9 - 1160,40) / (red. } \\
\text { br. 8) }\end{array}$ & $\mathbf{1 3 4 . 2 2 7 , 9 4 \downarrow}$ \\
\hline 11 & $\begin{array}{l}\text { Porez (red. br. 10 - red. br. 3) x (red. } \\
\text { br. 4.) }\end{array}$ & $\mathbf{1 2 . 2 6 2 , 3 9 \downarrow}$ \\
\hline 12 & $\begin{array}{l}\text { Doprinos za PIO na teret zaposlenog } \\
\text { (red. br. 5 x red. br. 10) }\end{array}$ & $\mathbf{1 8 . 7 9 1 , 9 1 \downarrow}$ \\
\hline 13 & $\begin{array}{l}\text { Doprinos za zdr.osig. na teret zaposle- } \\
\text { nog (red. br. 6 x red. br. 10) }\end{array}$ & $\mathbf{6 . 9 1 2 , 7 4 \downarrow}$ \\
\hline 14 & $\begin{array}{l}\text { Doprinos za osig. za sl. nez. na teret } \\
\text { zaposlenog (red. br. 7 x red. br. 10) }\end{array}$ & $\mathbf{1 . 0 0 6 , 7 1 \downarrow}$ \\
\hline & \multicolumn{2}{l}{}
\end{tabular}

Tabela 13. Obračun plate po bruto osnovici sa poreskom olakšicom

\begin{tabular}{|c|c|c|}
\hline Red. br. & Naziv & Iznos \\
\hline 1 & Bruto osnovica & $24.395,56$ \\
\hline 2 & Koeficijent & 5,57 \\
\hline 3 & Poreska olakšica & $11.604,00$ \\
\hline 4 & Stopa poreza na dohodak & $10,00 \%$ \\
\hline 5 & $\begin{array}{l}\text { Stopa doprinosa za PIO na teret zapos- } \\
\text { lenog }\end{array}$ & $14,00 \%$ \\
\hline 6 & $\begin{array}{l}\text { Stopa doprinosa za zdr.osig. na teret } \\
\text { zaposlenog }\end{array}$ & $5,15 \%$ \\
\hline 7 & $\begin{array}{l}\text { Stopa doprinosa za osig. za sl. nez. na } \\
\text { teret zaposlenog }\end{array}$ & $0,75 \%$ \\
\hline 8 & $\begin{array}{l}\text { Koeficijent za preračun } \\
1 \text { - (red. br. } 4 .+ \text { red. br. } 5 .+ \text { red. br. } 6+ \\
\text { red. br. } 7 \text { ) }\end{array}$ & 0,701 \\
\hline 9 & Bruto plata (red. br. $1 \mathrm{x}$ red. br. 2) & $135.883,29$ \\
\hline 10 & $\begin{array}{l}\text { Neto plata (red. br. } 9 \times \text { red. br. } 8 \text { + red. } \\
\text { br. } 3 \times \text { red. br. } 4 \text { ) }\end{array}$ & $96.414,59 \uparrow$ \\
\hline 11 & Porez (red. br. 9 - red. br. 3) x (red. br. 4.) & $12.427,93 \downarrow$ \\
\hline 12 & $\begin{array}{l}\text { Doprinos za PIO na teret zaposlenog } \\
\text { (red. br. } 5 \text { x red. br. 9) }\end{array}$ & $19.023,66$ \\
\hline 13 & $\begin{array}{l}\text { Doprinos za zdr.osig. na teret zaposlenog } \\
\text { (red. br. } 6 \text { x red. br. 9) }\end{array}$ & $6.997,99$ \\
\hline 14 & $\begin{array}{l}\text { Doprinos za osig. za sl. nez. na teret } \\
\text { zaposlenog (red. br. } 7 \text { x red. br. 9) }\end{array}$ & $1.019,12$ \\
\hline
\end{tabular}

Uvođenjem poreske olakšice, kod obračuna plate po neto osnovici, bruto plata odnosno visina obaveze po osnovu poreza i doprinosa se smanjuju, a neto plata ostaje nepromenjena. U slučaju obračuna plate po bruto osnovici, uvođenjem poreske olakšice bruto plata ostaje nepromenjena, a smanjuje se obaveza po osnovu plaćanja poreza uz istovremeno povećanje neto plate licu, za isti iznos razlike sa suprotnim predznakom (apsolutna vrednost razlike između visine neto plate pre poreske olakšice i visine neto plate nakon poreske olakšice ista je vrednosti razlike visine poreza pre i nakon primene poreske olakšice). Svako dalje povećanje poreske olakšice proizvodi isti efekat odnosno smanjenje poreske olakšice inicira obrnuti efekat. 
Primena minimalne zarade, najniže i najviše osnovice za plaćanje doprinosa

Minimalna zarada (Zakon o radu, čl. 112) je najniža cena po satu rada (uobičajeno je određena u neto iznosu odakle se preračunava u bruto iznos) koju imaju obavezu da primenjuju svi poslodavci koji poslovne aktivnosti obavljaju na teritoriji i prema opštim propisima o radu Republike Srbije. Budući da se ista primenjuje i u situacijama kada lice prima naknadu plate za opravdano odsustvovanje sa posla (bolovanje, usavršavanje, na poziv drugog državnog organa itd.), može se zaključiti da troškovi plate i naknade plate po licu ne mogu biti niži od cene koštanja minimalne zarade (bruto minimalna zarada sa doprinosima na teret poslodavca). U slučaju primene minimalne zarade, kod obe metode obračuna iznos neto i bruto plate ostaje isti. U situacijama kada zaposleni neopravdano odsustvuje sa posla, ili je udaljen sa posla, ili se nalazi u pritvoru, kada lice neće ostvarivati naknadu plate odnosno ostvarivaće određenu naknadu u neto iznosu nižem od minimalne zarade, mesečni doprinosi se po zakonskoj obavezi moraju platiti po najnižoj mesečnoj osnovici za plaćanje doprinosa (sve dok se lice nalazi u radnom odnosu kod poslodavca).

U slučaju primene najniže mesečne osnovice za plaćanje doprinosa, formula za obračun bruto prihoda izgledala bi:

Bruto prihod $=$ Neto iznos + Porez + Doprinosi na teret zaposlenog

Bruto prihod $=$ Neto iznos $+0,1 \times$ (Bruto prihod 11.604) + 0,199 x Najniža osnovica

Bruto prihod $=$ Neto iznos + 0,1 $\times$ Bruto prihod 1.160,4 + 0,199 x Najniža osnovica

Bruto prihod $x(1-0,1)=$ Neto iznos $-1.160,4+$ 0,199 x Najniža osnovica

Bruto prihod x 0,9 = Neto iznos $-1.160,4+0,199 x$ Najniža osnovica

Bruto prihod $=($ Neto iznos $-1.160,4+0,199 \times$ Najni-

ža osnovica) / 0,9

Kada se naknada ne odnosi na ceo mesec, koristi se srazmeran iznos poreske olakšice. Takođe, srazmeran iznos najniže mesečne osnovice za plaćanje doprinosa se određuje u slučaju da lice radi kod dva ili više poslodavaca. Obračun bruto prihoda izgledao bi:

$$
B P=\frac{N-1.160,4 \times \check{c} / m \check{c}+(N \check{z} m O \times 19.9 \%)}{0,9}
$$

BP - Bruto prihod (neto iznos sa porezom i doprinosima na teret zaposlenog),

$\mathrm{N}$ - Pripadajući neto iznos za isplatu,

č - Broj časova za koji se obračunava neto iznos,

mč - Mesečni fond sati rada u mesecu.

NžmO - Najniža mesečna osnovica za plaćanje doprinosa,

Kako se kod budžetskih korisnika najniža mesečna osnovica za plaćanje doprinosa koristi u specifičnim situacijama, ne može se odrediti opšte pravilo u poreskim implikacijama u zavisnosti od metode obračuna plate. Posebno je problematično, kod slučaja obračuna plate po bruto osnovici, logikom računske operacije usled uvećanja doprinosa pri nepromenjenoj bruto naknadi treba smanjiti neto iznos za isplatu, što ugrožava egzistenciju lica, pa se često u praksi primenjuju različita pozitivna pravna rešenja radi prevazilaženja ovih situacija. Obaveza primene najviše mesečne osnovice za plaćanje doprinosa kod budžetskih korisnika može nastupiti kada se licu pored redovne plate isplaćuje naknada za neiskorišćeni godišnji odmor u visini mesečne plate (sastavlja se jedna elektronska pojedinačna poreska prijava gde se pod istom šifrom vrste prihoda za zaradu, prijavljuje prihod po osnovu redovne plate i naknade za isti obračunski period, obzirom da se naknada ne može prijaviti za raniji obračunski period). U slučaju primene najviše mesečne osnovice za plaćanje doprinosa, formula za obračun bruto prihoda izgledala bi:

$$
B P=\frac{N-1.160,4 \times \check{c} / m \check{c}+(\mathrm{N} v m O \times 19.9 \%)}{0,9}
$$

BP - Bruto prihod (neto iznos sa porezom i doprinosima na terete zaposlenog),

$\mathrm{N}$ - Pripadajući neto iznos za isplatu,

č - Broj časova za koji se obračunava neto iznos,

mč - Mesečni fond sati rada u mesecu,

NvmO - Najviša mesečna osnovica za plaćanje doprinosa.

I u ovom slučaju, kada se bruto prihod ne odnosi na ceo mesec, koristi se srazmeran iznos poreske olakšice. Sa druge strane, propisani iznos najviše mesečne osnovice za plaćanje doprinosa koristi se u punom iznosu za jedno lice bez obzira da li lice prima prihod za ceo mesec ili deo meseca. Ukoliko lice radi kod više poslodavaca, određuje se srazmeran iznos najviše osnovice, shodno stepenu angažovanosti lica kod poslodavca u odnosu na puno radno vreme. Primena najviše mesečne osnovice za plaćanje doprinosa izaziva različite efekte u zavisnosti od metode obračuna plate. Kod metode obračuna plate po neto osnovici, efekat se može sagledati poređenjem rezultata primera gde se najviša osnovica nije koristila i primera gde je primenjena. 
Tabela 14. Obračun plate po neto osnovici, bez primene najviše mesečne osnovice za plaćanje doprinosa

\begin{tabular}{|c|c|c|}
\hline Red. br. & Naziv & Iznos \\
\hline 1 & Neto osnovica & $17.101,29$ \\
\hline 2 & Koeficijent & 7,11 \\
\hline 3 & Poreska olakšica & $11.604,00$ \\
\hline 4 & Stopa poreza na dohodak & $10,00 \%$ \\
\hline 5 & Stopa doprinosa za PIO na teret zaposlenog & $14,00 \%$ \\
\hline 6 & $\begin{array}{l}\text { Stopa doprinosa za zdr.osig. na teret zapos- } \\
\text { lenog }\end{array}$ & $5,15 \%$ \\
\hline 7 & $\begin{array}{l}\text { Stopa doprinosa za osig. za sl. nez. na teret } \\
\text { zaposlenog }\end{array}$ & $0,75 \%$ \\
\hline 8 & Neto plata (red. br. $1 \mathrm{x}$ red. br. 2) & $121.590,17$ \\
\hline 9 & $\begin{array}{l}\text { Neto naknada za neiskorišćeni godišnji } \\
\text { odmor }\end{array}$ & $121.590,17$ \\
\hline 10 & $\begin{array}{l}\text { Bruto prihod } \\
\text { (red. br. } 8+\text { red. br. } 9 \text { - red. br. } 3 \text { x red. br. } \\
4) /(1 \text { - (red. br. } 4+\text { red. br. } 5+\text { red. br. } 6+ \\
\text { red. br. } 7))\end{array}$ & $345.249,56$ \\
\hline 11 & Porez (red. br. 10 - red. br. 3) x (red. br. 4.) & $33.364,56$ \\
\hline 12 & Osnovica za plaćanje doprinosa (red. br. 10) & $345.249,56$ \\
\hline 13 & $\begin{array}{l}\text { Doprinos za PIO na teret zaposlenog (red. br. } \\
5 \text { x red. br. 12) }\end{array}$ & $48.334,94$ \\
\hline 14 & $\begin{array}{l}\text { Doprinos za zdr.osig. na teret zaposlenog } \\
\text { (red. br. } 6 \text { x red. br. 12) }\end{array}$ & $17.780,35$ \\
\hline 15 & $\begin{array}{l}\text { Doprinos za osig. za sl. nez. na teret zaposle- } \\
\text { nog (red. br. } 7 \text { x red. br. 12) }\end{array}$ & $2.589,37$ \\
\hline 16 & $\begin{array}{l}\text { Neto prihod (red. br. } 10 \text { - (red. br. } 11 \text { + red. } \\
\text { br. } 13 \text { + red. br. } 14 \text { + red. br. } 15) \text { ) }\end{array}$ & $243.180,34$ \\
\hline
\end{tabular}

Tabela 15. Obračun plate po neto osnovici, sa primenom najviše mesečne osnovice za plaćanje doprinosa

\begin{tabular}{|c|c|c|}
\hline Red. br. & Naziv & Iznos \\
\hline 1 & Neto osnovica & $17.101,29$ \\
\hline 2 & Koeficijent & 7,11 \\
\hline 3 & Poreska olakšica & $11.604,00$ \\
\hline 4 & Stopa poreza na dohodak & $10,00 \%$ \\
\hline 5 & Stopa doprinosa za PIO na teret zaposlenog & $14,00 \%$ \\
\hline 6 & $\begin{array}{l}\text { Stopa doprinosa za zdr.osig. na teret zapos- } \\
\text { lenog }\end{array}$ & $5,15 \%$ \\
\hline 7 & $\begin{array}{l}\text { Stopa doprinosa za osig. za sl. nez. na teret } \\
\text { zaposlenog }\end{array}$ & $0,75 \%$ \\
\hline 8 & Neto plata (red. br. 1 x red. br. 2) & $121.590,17$ \\
\hline 9 & $\begin{array}{l}\text { Neto naknada za neiskorišćeni godišnji } \\
\text { odmor }\end{array}$ & $121.590,17$ \\
\hline 10 & $\begin{array}{l}\text { Bruto prihod } \\
\text { (red. br. } 8+\text { red. br. } 9 \text { - red. br. } 3 \times \text { red. br. } \\
4+\text { red. br. } 12 \times(\text { red. br. } 5 \text { + red. br. } 6 \text { + red. } \\
\text { br. } 7)) /(1 \text { - red. br. } 4)\end{array}$ & $336.658,39 \downarrow$ \\
\hline 11 & Porez (red. br. 10 - red. br. 3) x (red. br. 4.) & $32.505,44 \downarrow$ \\
\hline 12 & $\begin{array}{l}\text { Najviša mesečna osnovica za plaćanje } \\
\text { doprinosa za mesec april } 2016\end{array}$ & $306.395,00$ \\
\hline 13 & $\begin{array}{l}\text { Doprinos za PIO na teret zaposlenog (red. } \\
\text { br. } 5 \text { x red. br. 12) }\end{array}$ & $42.895,30 \downarrow$ \\
\hline 14 & $\begin{array}{l}\text { Doprinos za zdr.osig. na teret zaposlenog } \\
\text { (red. br. } 6 \text { x red. br. 12) }\end{array}$ & $15.779,34 \downarrow$ \\
\hline
\end{tabular}

\begin{tabular}{clc}
\hline Red. br. & \multicolumn{1}{c}{ Naziv } & Iznos \\
\hline 15 & $\begin{array}{l}\text { Doprinos za osig. za sl. nez. na teret zapos- } \\
\text { lenog (red. br. 7 x red. br. 12) }\end{array}$ & $\mathbf{2 . 2 9 7 , 9 6 \downarrow}$ \\
\hline 16 & $\begin{array}{l}\text { Neto prihod (red. br. 10 - (red. br. 11 + } \\
\text { red. br. 13 + red. br. 14 + red. br. 15)) }\end{array}$ & $\mathbf{2 4 3 . 1 8 0 , 3 4}$ \\
\hline
\end{tabular}

Kao što se može uočiti u gornjim primerima, usled primene najviše mesečne osnovice za plaćanje doprinosa kod slučaja obračuna plate po neto osnovici smanjuju se: bruto prihod, osnovica za plaćanje poreza, osnovica za plaćanje doprinosa, troškovi poreza i doprinosa, uz nepromenjeni neto prihod licu. Kod metode obračuna plate po bruto osnovici, efekti primene najviše mesečne osnovice za plaćanje doprinosa se mogu sagledati kroz sledeće primere:

Tabela 16. Obračun plate po bruto osnovici bez primene najviše mesečne osnovice za plaćanje doprinosa

\begin{tabular}{|c|c|c|}
\hline Red. br. & Naziv & Iznos \\
\hline 1 & Bruto osnovica & $24.279,15$ \\
\hline 2 & Koeficijent & 7,11 \\
\hline 3 & Poreska olakšica & $11.604,00$ \\
\hline 4 & Stopa poreza na dohodak & $10,00 \%$ \\
\hline 5 & Stopa doprinosa za PIO na teret zaposlenog & $14,00 \%$ \\
\hline 6 & $\begin{array}{l}\text { Stopa doprinosa za zdr.osig. na teret zapos- } \\
\text { lenog }\end{array}$ & $5,15 \%$ \\
\hline 7 & $\begin{array}{l}\text { Stopa doprinosa za osig. za sl. nez. na teret } \\
\text { zaposlenog }\end{array}$ & $0,75 \%$ \\
\hline 8 & Bruto plata (red. br. 1 x red. br. 2) & $172.624,78$ \\
\hline 9 & $\begin{array}{l}\text { Bruto naknada za neiskorišćeni godišnji } \\
\text { odmor }\end{array}$ & $172.624,78$ \\
\hline 10 & Bruto prihod (red. br. 8 + red. br. 9) & $345.249,56$ \\
\hline 11 & Porez (red. br. 10 - red. br. 3) x (red. br. 4.) & $33.364,56$ \\
\hline 12 & Osnovica za plaćanje doprinosa (red. br. 10) & $345.249,56$ \\
\hline 13 & $\begin{array}{l}\text { Doprinos za PIO na teret zaposlenog (red. br. } \\
5 \text { x red. br. } 12 \text { ) }\end{array}$ & $48.334,94$ \\
\hline 14 & $\begin{array}{l}\text { Doprinos za zdr.osig. na teret zaposlenog } \\
\text { (red. br. } 6 \text { x red. br. 12) }\end{array}$ & $17.780,35$ \\
\hline 15 & $\begin{array}{l}\text { Doprinos za osig. za sl. nez. na teret zaposle- } \\
\text { nog (red. br. } 7 \text { x red. br. 12) }\end{array}$ & $2.589,37$ \\
\hline 16 & $\begin{array}{l}\text { Neto prihod (red. br. } 10 \text { - (red. br. } 11+\text { red. } \\
\text { br. } 13 \text { + red. br. } 14 \text { + red. br. 15)) }\end{array}$ & $243.180,34$ \\
\hline
\end{tabular}

Tabela 17. Obračun plate po bruto osnovici sa primenom najviše mesečne osnovice za plaćanje doprinosa

\begin{tabular}{clr}
\hline Red. br. & \multicolumn{1}{c}{ Naziv } & \multicolumn{1}{c}{ Iznos } \\
\hline $\mathbf{1}$ & Bruto osnovica & $\mathbf{2 4 . 2 7 9 , \mathbf { 1 5 }}$ \\
\hline 2 & Koeficijent & 7,11 \\
\hline 3 & Poreska olakšica & $11.604,00$ \\
\hline 4 & Stopa poreza na dohodak & $10,00 \%$ \\
\hline 5 & $\begin{array}{l}\text { Stopa doprinosa za PIO na teret } \\
\text { zaposlenog }\end{array}$ & $14,00 \%$ \\
\hline
\end{tabular}




\begin{tabular}{|c|c|c|}
\hline Red. br. & Naziv & Iznos \\
\hline 6 & $\begin{array}{l}\text { Stopa doprinosa za zdr.osig. na teret } \\
\text { zaposlenog }\end{array}$ & $5,15 \%$ \\
\hline 7 & $\begin{array}{l}\text { Stopa doprinosa za osig. za sl. nez. na } \\
\text { teret zaposlenog }\end{array}$ & $0,75 \%$ \\
\hline 8 & Bruto plata (red. br. $1 \mathrm{x}$ red. br. 2) & $172.624,78$ \\
\hline 9 & $\begin{array}{l}\text { Bruto naknada za neiskorišćeni godišnji } \\
\text { odmor }\end{array}$ & $172.624,78$ \\
\hline 10 & Bruto prihod (red. br. 8 + red. br. 9) & $345.249,56$ \\
\hline 11 & $\begin{array}{l}\text { Porez (red. br. } 10 \text { - red. br. 3) x (red. } \\
\text { br. 4.) }\end{array}$ & $33.364,56$ \\
\hline 12 & $\begin{array}{l}\text { Najviša mesečna osnovica za plaćanje } \\
\text { doprinosa }\end{array}$ & $306.395,00$ \\
\hline 13 & $\begin{array}{l}\text { Doprinos za PIO na teret zaposlenog } \\
\text { (red. br. } 5 \text { x red. br. 12) }\end{array}$ & $42.895,30 \downarrow$ \\
\hline 14 & $\begin{array}{l}\text { Doprinos za zdr.osig. na teret zaposle- } \\
\text { nog (red. br. } 6 \text { x red. br. 12) }\end{array}$ & $15.779,34 \downarrow$ \\
\hline 15 & $\begin{array}{l}\text { Doprinos za osig. za sl. nez. na teret } \\
\text { zaposlenog (red. br. } 7 \text { x red. br. 12) }\end{array}$ & $2.297,96 \downarrow$ \\
\hline 16 & $\begin{array}{l}\text { Neto prihod (red. br. } 10 \text { - (red. br. } 11+ \\
\text { red. br. } 13+\text { red. br. } 14+\text { red. br. } 15))\end{array}$ & $250.912,40 \uparrow$ \\
\hline
\end{tabular}

Za razliku od slučaja obračuna plate po neto osnovici, primena najviše mesečne osnovice za plaćanje doprinosa kod metode obračuna plate po bruto osnovici ne menja bruto iznos za isplatu, s tim da se za isti iznos smanjuju doprinosi na teret zaposlenog odnosno uvećava neto prihod. Sa druge strane, iako je bruto prihod ostao nepromenjen, troškovi doprinosa na teret poslodavca su se smanjili usled plaćanja po manjem iznosu osnovice, tako da je ukupan trošak plate smanjen i u slučaju obračuna plate po bruto osnovici.

\section{TREND KRETANJA STOPE POREZA I DOPRINOSA}

Od početka primene, do poslednjih izmena i dopuna Zakona o porezu na dohodak građana odnosno Zakona o doprinosima za obavezno socijalno osiguranje, stope poreza i doprinosa kretale su se prema sledećoj tabeli:

Tabela 18. Pregled stope poreza i doprinosa na teret zaposlenog i poreskih olakšica na zaradu za zaposlene, bez dodatnih poreskih olakšica za posebne slučajeve i kategorije lica

\begin{tabular}{|c|c|c|c|c|c|c|c|c|}
\hline \multicolumn{2}{|c|}{ Period primene } & \multirow{2}{*}{$\begin{array}{l}\text { koef. za } \\
\text { preračun }\end{array}$} & \multirow{2}{*}{$\begin{array}{l}\text { zbirna } \\
\text { stopa }\end{array}$} & \multirow{2}{*}{$\begin{array}{l}\text { poreska } \\
\text { olakšica }\end{array}$} & \multirow[b]{2}{*}{ porez } & \multicolumn{3}{|c|}{ doprinosi na teret zaposlenog } \\
\hline od & do & & & & & $\begin{array}{c}\text { dopr. za } \\
\text { PIO }\end{array}$ & $\begin{array}{c}\text { dopr. za } \\
\text { zdrav. osig. }\end{array}$ & $\begin{array}{c}\text { dopr. za } \\
\text { nezap. }\end{array}$ \\
\hline 1.6 .2001 & 30.4 .2003 & 0,697 & $30,30 \%$ & 0 & $14,00 \%$ & $9,80 \%$ & $5,95 \%$ & $0,55 \%$ \\
\hline 1.5 .2003 & 30.6 .2004 & 0,692 & $30,80 \%$ & 0 & $14,00 \%$ & $10,30 \%$ & $5,95 \%$ & $0,55 \%$ \\
\hline 1.7.2004 & 31.12 .2006 & 0,681 & $31,90 \%$ & 0 & $14,00 \%$ & $11,00 \%$ & $6,15 \%$ & $0,75 \%$ \\
\hline 1.1 .2007 & 31.1 .2008 & 0,701 & $29,90 \%$ & 5.000 & $12,00 \%$ & $11,00 \%$ & $6,15 \%$ & $0,75 \%$ \\
\hline 1.2 .2008 & 31.1 .2009 & 0,701 & $29,90 \%$ & 5.560 & $12,00 \%$ & $11,00 \%$ & $6,15 \%$ & $0,75 \%$ \\
\hline 1.2.2009 & 31.1 .2010 & 0,701 & $29,90 \%$ & 5.938 & $12,00 \%$ & $11,00 \%$ & $6,15 \%$ & $0,75 \%$ \\
\hline 1.2 .2010 & 31.1 .2011 & 0,701 & $29,90 \%$ & 6.554 & $12,00 \%$ & $11,00 \%$ & $6,15 \%$ & $0,75 \%$ \\
\hline 1.2 .2011 & 31.1 .2012 & 0,701 & $29,90 \%$ & 7.310 & $12,00 \%$ & $11,00 \%$ & $6,15 \%$ & $0,75 \%$ \\
\hline 1.2 .2012 & 31.1 .2013 & 0,701 & $29,90 \%$ & 7.822 & $12,00 \%$ & $11,00 \%$ & $6,15 \%$ & $0,75 \%$ \\
\hline 1.2 .2013 & 29.5 .2013 & 0,701 & $29,90 \%$ & 8.776 & $12,00 \%$ & $11,00 \%$ & $6,15 \%$ & $0,75 \%$ \\
\hline 30.5 .2013 & 31.1 .2014 & 0,701 & $29,90 \%$ & 11.000 & $10,00 \%$ & $13,00 \%$ & $6,15 \%$ & $0,75 \%$ \\
\hline 1.2 .2014 & 31.7 .2014 & 0,701 & $29,90 \%$ & 11.242 & $10,00 \%$ & $13,00 \%$ & $6,15 \%$ & $0,75 \%$ \\
\hline 1.8 .2014 & 31.1 .2015 & 0,701 & $29,90 \%$ & 11.242 & $10,00 \%$ & $14,00 \%$ & $5,15 \%$ & $0,75 \%$ \\
\hline 1.2 .2015 & 31.1 .2016 & 0,701 & $29,90 \%$ & 11.433 & $10,00 \%$ & $14,00 \%$ & $5,15 \%$ & $0,75 \%$ \\
\hline 1.2 .2016 & 31.1 .2017 & 0,701 & $29,90 \%$ & 11.604 & $10,00 \%$ & $14,00 \%$ & $5,15 \%$ & $0,75 \%$ \\
\hline
\end{tabular}


Tabela 19. Pregled stope doprinosa na teret poslodavca

\begin{tabular}{|c|c|c|c|c|c|c|c|c|}
\hline \multicolumn{2}{|c|}{ Period primene } & \multicolumn{7}{|c|}{ doprinosi na teret poslodavca } \\
\hline od & do & $\begin{array}{l}\text { dopr. za } \\
\text { PIO }\end{array}$ & $\begin{array}{c}\text { dopr. za } \\
\text { zdrav. osig. }\end{array}$ & $\begin{array}{c}\text { dopr. za } \\
\text { sluč. nezap. }\end{array}$ & $\begin{array}{c}\text { dopr. za } \\
\text { staž sa } \\
\text { uveć. traj. } \\
12 / 14\end{array}$ & $\begin{array}{c}\text { dopr. za } \\
\text { staž sa } \\
\text { uveć. traj. } \\
12 / 15\end{array}$ & $\begin{array}{c}\text { dopr. za } \\
\text { staž sa } \\
\text { uveć. traj. } \\
12 / 16\end{array}$ & $\begin{array}{c}\text { dopr. za } \\
\text { staž sa } \\
\text { uveć. traj. } \\
\text { 12/18 }\end{array}$ \\
\hline 1.6.2001 & 30.4 .2003 & $9,80 \%$ & $5,95 \%$ & $0,55 \%$ & $3,30 \%$ & $4,90 \%$ & $6,50 \%$ & $9,80 \%$ \\
\hline 1.5.2003 & 30.6 .2004 & $9,80 \%$ & $5,95 \%$ & $0,55 \%$ & $3,30 \%$ & $4,90 \%$ & $6,50 \%$ & $9,80 \%$ \\
\hline 1.7.2004 & 31.12 .2006 & $11,00 \%$ & $6,15 \%$ & $0,75 \%$ & $3,70 \%$ & $5,50 \%$ & $7,30 \%$ & $11,00 \%$ \\
\hline 1.1.2007 & 31.1 .2008 & $11,00 \%$ & $6,15 \%$ & $0,75 \%$ & $3,70 \%$ & $5,50 \%$ & $7,30 \%$ & $11,00 \%$ \\
\hline 1.2 .2008 & 31.1.2009 & $11,00 \%$ & $6,15 \%$ & $0,75 \%$ & $3,70 \%$ & $5,50 \%$ & $7,30 \%$ & $11,00 \%$ \\
\hline 1.2.2009 & 31.1 .2010 & $11,00 \%$ & $6,15 \%$ & $0,75 \%$ & $3,70 \%$ & $5,50 \%$ & $7,30 \%$ & $11,00 \%$ \\
\hline 1.2 .2010 & 31.1.2011 & $11,00 \%$ & $6,15 \%$ & $0,75 \%$ & $3,70 \%$ & $5,50 \%$ & $7,30 \%$ & $11,00 \%$ \\
\hline 1.2 .2011 & 31.1 .2012 & $11,00 \%$ & $6,15 \%$ & $0,75 \%$ & $3,70 \%$ & $5,50 \%$ & $7,30 \%$ & $11,00 \%$ \\
\hline 1.2 .2012 & 31.1 .2013 & $11,00 \%$ & $6,15 \%$ & $0,75 \%$ & $3,70 \%$ & $5,50 \%$ & $7,30 \%$ & $11,00 \%$ \\
\hline 1.2 .2013 & 29.5.2013 & $11,00 \%$ & $6,15 \%$ & $0,75 \%$ & $3,70 \%$ & $5,50 \%$ & $7,30 \%$ & $11,00 \%$ \\
\hline 30.5 .2013 & 31.1 .2014 & $11,00 \%$ & $6,15 \%$ & $0,75 \%$ & $3,70 \%$ & $5,50 \%$ & $7,30 \%$ & $11,00 \%$ \\
\hline 1.2.2014 & 31.7.2014 & $11,00 \%$ & $6,15 \%$ & $0,75 \%$ & $3,70 \%$ & $5,50 \%$ & $7,30 \%$ & $11,00 \%$ \\
\hline 1.8.2014 & 31.1 .2015 & $12,00 \%$ & $5,15 \%$ & $0,75 \%$ & $3,70 \%$ & $5,50 \%$ & $7,30 \%$ & $11,00 \%$ \\
\hline 1.2 .2015 & 31.1 .2016 & $12,00 \%$ & $5,15 \%$ & $0,75 \%$ & $3,70 \%$ & $5,50 \%$ & $7,30 \%$ & $11,00 \%$ \\
\hline 1.2 .2016 & 31.1 .2017 & $12,00 \%$ & $5,15 \%$ & $0,75 \%$ & $3,70 \%$ & $5,50 \%$ & $7,30 \%$ & $11,00 \%$ \\
\hline
\end{tabular}

Do kraja 2006. godine, zbirna stopa poreza i doprinosa na teret zaposlenog imala je rastući trend, da bi se početkom 2007. godine snizila, od kada se nije menjala. Takođe, od 2007. godine uvedena je poreska olakšica, koja se godišnje uvećavala prema stopi rasta cena na malo u kalendarskoj godini koja je prethodila godini u kojoj se usklađivanje vrši. U ovakvom poreskom okruženju sa tendencijom povećanja poreske olakšice, s obzirom da neto osnovica za obračun plate nema veću stopu rasta od bruto osnovice za obračun plate, zaposleni kojima se plata obračunava po bruto osnovici ostvarivaće veće pravo na penzijsko osiguranje u odnosu i na račun zaposlenih kojima se plata obračunava po neto osnovici.

\section{IZBOR NAJPOVOLJNIJE METODE ZA OBRAČUN PLATE}

Uzimajući u obzir postojeći način obračuna poreza i doprinosa iz plate kao i trend kretanja poreske stope, stopa doprinosa i poreske olakšice, metoda obračuna plate po neto osnovici odgovara poslodavcima, jer ostvaruju uštede po osnovu poreskog rasterećenja. Sa druge strane, metoda obračuna plate po bruto osnovici odgovara zaposlenima, koji uz svako novo poresko rasterećenje ostvaruju izvesno uvećanje neto plate i veće penzijsko osiguranje. U slučaju pooštravanja fiskalnih obaveza - uvećanja poreske stope, stope doprinosa ili smanjenja poreskih olakšica, metoda obračuna plate po bruto osnovici odgovarala bi poslodavcu usled nepromenjenog troška bruto plate (eventualno bi se uvećao trošak po osnovu doprinosa na teret poslodavca, ali bi ukupan trošak plate po bruto osnovici bio niži u odnosu na to da je plata obračunavana po neto osnovici), dok bi metoda obračuna plate po neto osnovici pogodovala zaposlenima, kojima bi se u tom slučaju uvećavao penzijski osnov. Ukoliko bi se za sve zaposlene kod budžetskih korisnika uveo obračun plate po neto osnovici (prelaz sa bruto na neto osnovicu najverovatnije bi se izvršio množenjem bruto iznosa sa koeficijentom 0,701 ), zaposleni u privrednom sektoru kojima se zarada obračunava po bruto osnovici ostvarivali bi veće pravo na penzijsko osiguranje na uštrb zaposlenih kojima se plate/zarade obračunavaju po neto osnovici, što bi se dalje uvećavalo novim poreskim olakšicama, ili smanjenjem poreske stope, ili smanjenjem stope doprinosa za zdravstveno osguranje, ili 
smanjenjem stope doprinosa za slučaj nezaposlenosti, a što ne bi trebalo da utiče na visinu prava na penzijsko osiguranje lica (osim kada je u pitanju promena stope doprinosa za penzijsko osiguranje). Eventualni prelaz na neto princip obračuna poreza i doprinosa, tj. na neto zaradu/platu uz odgovarajuću nivelaciju neto odnosno bruto osnovice za obračun plate/ zarade, značajno bi uprostio obračun poreskih obaveza. Takođe, to bi dovelo do smanjenja javnih prihoda po osnovu poreza i doprinosa na zarade, što je neodrživo sa nivoom trenutnih javnih rashoda. Izmena sadašnjeg načina obračuna penzije, tako što bi se godišnja neto zarada/plata lica stavljala u odnos sa godišnjom prosečnom neto zaradom u Republici Srbiji, odakle bi se dalje izvodio lični koeficijent, onemogućila bi da poresko rasterećenje na posredan način negativno utiče na penzijsko osiguranje velikog broja zaposlenih (sprečio bi se negativni uticaj smanjenja stope doprinosa za zdravstveno osiguranje i za slučaj nezaposlenosti).

Prema podacima iz Fiskalne strategije Vlade za 2016. godinu sa projekcijama za 2017. i 2018. godinu (tabela 5: Prihodi, rashodi i rezultat sektora države u 2015. godini - budžet i procena zasnovana na trećoj reviziji aranžmana sa MMF) javni prihodi po osnovu poreza na dohodak (čiji najveći deo čini porez na zarade) i doprinosa skoro dvostruko prevazilaze prihode po osnovu poreza na dobit pravnih lica (koji predstavlja primarni izvor javnih prihoda u razvijenim ekonomijama, tzv. "corporate tax"). Uzrok ovakvog stanja nije dovoljno tražiti u slabim rezultatima privrednih subjekata, potrebno je analizirati i rashodnu stranu po osnovu poreza i doprinosa na zarade. Nasleđeni model dvostrukog zaračunavanja doprinosa po istoj osnovici, u slučaju prosečne neto zarade za jun 2016. godine (44,583 dinara), generiše trošak na ime poreza i doprinosa u visini 28.448,73 dinara, ili 63,81\% neto zarade. Drugim rečima, na svakih 100 dinara prosečne neto zarade isplaćene u junu 2016. godine obračunava se 63,81 dinar fiskalnih davanja, što je značajno opterećenje. Zagovornici reforme poreskog sistema (Arsić et al., 2010), predlažu fiskalno rasterećenje zarada, npr. ukidanjem doprinosa za zdravstveno osiguranje i za slučaj nezaposlenosti (uz povećanje poreza na dodatu vrednost). Sa jedne strane, ovo bi stimulisalo zapošljavanje i otvaranje novih radnih mesta. Sa druge strane, smanjilo bi bruto zaradu (po neto osnovici) iz prosečne neto zarade za jun 2016, za skoro osam procentnih poena. Ako se poreska olakšica odredi najmanje u visini prosečne mesečne potrošačke korpe (koja je za maj 2016. godine iznosila 67.117,80 dinara), smanjila bi se bruto zarada (po neto osnovici) iz neto zarade na nivou prosečne mesečne potrošačke korpe, za najmanje osam procentnih poena (za niže zarade iznosilo bi više), što bi derogiralo individualno penzijsko osiguranje.

\section{ZAKLJUČAK}

U radu je izloženo teorijsko i praktično izučavanje poreskih implikacija u zavisnosti od metoda obračuna plate budžetskih korisnika, pri čemu se izvedeni zaključci podjednako odnose na sektor države i privrede. Analiza slučaja metoda obračuna plate kroz efekte promene poreskih komponenata pokazala je rezultate kojima se dovodi u pitanje smisao ugrađenih rešenja u sadašnjem modelu obračuna poreza i doprinosa na zarade, odnosno načinu na koji se određuje visina penzije. Naime, mehanizmi promene elemenata poreskog sistema ili sistema obračuna plate u sprezi sa sistemom penzijskog osiguranja trenutno su neusklađeni. U zavisnosti od situacije, jedna kategorija lica ostvaruje korist na štetu druge. Logično je zapitati se, da li usled nepromenjene visine neto zarade (plate) i stope doprinosa za penzijsko i invalidsko osiguranje, a promenom drugih poreskih elemenata i stopa doprinosa (za zdravstveno osiguranje ili za osiguranje za slučaj nezaposlenosti), treba da se menja visina prava iz penzijskog osiguranja?

Privredni ili budžetski subjekti nastoje sniziti troškove poslovanja, odabir metode obračuna zarade po neto osnovici (ili po neto ceni rada po času) dugoročno će smanjiti trošak zarade (usled trenda kretanja poreskih komponenata) bez rizika neusaglašenosti sa zakonom. Međutim, postoji rizik da će se ovakvo postupanje negativno odraziti na zaposlene (koji nemaju visoke zarade) što bi dalje podrivalo aktivnosti, odnosno poslovni ugled entiteta.

\section{LITERATURA}

Arsić, M., Altiparmakov, N., \& Ranđelović, S. (2010). Poreska politika u Srbiji: pogled unapred. Beograd: USAID Sega projekat.

Barjaktarović, L. (2009). Upravljanje rizikom. Beograd: Univerzitet Singidunum.

Cvetinović, M. (2008). Upravljanje rizicima u finansijskom poslovanju. Beograd: Univerzitet Singidunum.

Hull, J.C. (2012). Risk Management and Financial Institutions. New Jersey: John Wiley \& Sons.

Iverson, D. (2012). Strategic Risk Management. Singapore: John Wiley \& Sons.

Jezdimirović, M. (2011). Efikasnost budžetskog sistema Srbije. Beograd: Univerzitet Singidunum.

Kulić, M., \& Milošević, G. (2011). Poresko pravo: teorija i praksa. Beograd: Marso.

Ministarstvo finansija Republike Srbije. (2015). Fiskalna strategija za 2016. godinu sa projekcijama za 2017. i 2018. godinu. http://www.mfin.gov.rs/UserFiles/File/dokumenti/2015/Fiskalna\%20strategija\%20za\%202016_\%20godinu\%20sa\%20 projekcijama\%20za\%202017_\%20i\%202018_\%20godinu. pdf, Datum preuzimanja 20.02.2016.

Pritchard, C. (2015). Risk management: Concepts and Guidance. Boca Raton, USA: CRC press, Taylor \& Francis Group.

Raičević, B. (2010). Javne finansije. Beograd: Ekonomski fakultet. Službeni glasnik RS. (2001). Zakon o porezu na dohodak građana. Službeni glasnik RS br. 24/2001, 80/2002, 80/2002 - dr. zakon, 135/2004, 62/2006, 65/2006 - ispr., 31/2009, 44/2009, 18/2010, 50/2011, 91/2011 - odluka US, 7/2012 - 
usklađeni din. izn., 93/2012, 114/2012 - odluka US, 8/2013 - usklađeni din. izn., 47/2013, 48/2013 - ispr., 108/2013, 6/2014 - usklađeni din. izn., 57/2014, 68/2014 - dr. zakon, 5/2015 - usklađeni din. izn., 112/2015 i 5/2016 - usklađeni din. izn.)

Službeni glasnik RS. (2002). Zakon o poreskom postupku i poreskoj administraciji. Službeni glasnik RS br. 80/02, 84, 23/03, 70/03, 55/04, 61/05, 85/05, 62/06, 63/06, 61/07, 20/09, 72/09, 53/10,101/11, 2/12, 93/12, 47/13, 108/13, $68 / 14,105 / 14,91 / 15$ i 112/15.

Službeni glasnik RS. (2003). Zakon o penzijskom i invalidskom osiguranju. Sl. glasnik RS br. 34/03, 64/04, 84/04, 85/05, $101 / 05,63 / 06,5 / 09,107 / 09,101 / 10,93 / 12,62 / 13,108 / 13$, $75 / 14$ i 142/14)

Službeni glasnik RS. (2004). Zakon o doprinosima za obavezno socijalno osiguranje. Službeni glasnik RS br. 84/2004, 61/2005, 62/2006, 5/2009, 52/2011, 101/2011, 7/2012 usklađeni din. izn., 8/2013 - usklađeni din. izn., 47/2013, 108/2013, 6/2014 - usklađeni din. izn., 57/2014, 68/2014 - dr. zakon, 5/2015 - usklađeni din. izn., 112/2015 i 5/2016 - usklađeni din. izn.
Službeni glasnik RS. (2005). Zakon o radu. Službeni glasnik RS br. 24/2005, 61/2005, 54/2009, 32/2013 i 75/2014.

Službeni glasnik RS. (2006). Zakon o platama državnih službenika i nameštenika. Službeni glasnik RS br. 62/2006, 63/2006 - ispr., 115/2006 - ispr., 101/2007, 99/2010, 108/2013 i 99/2014.

Službeni glasnik RS. (2007). Zakon o Vojsci Srbije. Službeni glasnik RS br. 116/2007, 88/2009, 101/2010, 10/2015 i $88 / 2015$.

Službeni glasnik RS. (2009). Zakon o budžetskom sistemu. Službeni glasnik RS br. 54/2009, 73/2010, 101/2010, 101/2011, 93/2012, 62/2013, 63/2013, 108/2013, 142/2014, 68/2015 - dr. zakon i 103/2015.

Službeni glasnik RS. (2015). Zakon o budžetu Republike Srbije za 2016. godinu. Službeni glasnik RS br. 103/15.

Službeni glasnik RS. (2016). Zakon o sistemu plata zaposlenih u javnom sektoru. Službeni glasnik RS, br. 18/2016.

Vukša, S. (2011). Poreska i budžetska kontrola i revizija. Beograd: EtnoStil.

\section{TAX IMPLICATIONS OF THE METHOD OF CALCULATING THE EARNINGS FOR BUDGET USERS}

\section{Abstract:}

The regulations in the field of taxation and social security in the Republic of Serbia did not change conceptually despite the fact that the economic structure of the country has basically changed several years ago. The current model of double charging of the contributions (from earnings and on earnings) is, in fact, an inherited model, which had a primary aim to provide (besides health insurance) pension insurance for employees. This paper will point out the existing gap between the tax system and pension system in the Republic of Serbia, and that, in addition to causing a significant tax burden for the employer, there is a category of employees whose pension basis is increased at the expense of other categories of employees.

\section{Keywords:}

the methods of calculating wages, costs of tax and contribution, tax impact on pension insurance. 